\title{
Organic methods to control root rot of peas and spinach in north- central West Virginia
}

\author{
Hannah Witten Schrum \\ West Virginia University
}

Follow this and additional works at: https://researchrepository.wvu.edu/etd

\section{Recommended Citation}

Schrum, Hannah Witten, "Organic methods to control root rot of peas and spinach in north-central West Virginia" (2008). Graduate Theses, Dissertations, and Problem Reports. 2618.

https://researchrepository.wvu.edu/etd/2618

This Thesis is protected by copyright and/or related rights. It has been brought to you by the The Research Repository @ WVU with permission from the rights-holder(s). You are free to use this Thesis in any way that is permitted by the copyright and related rights legislation that applies to your use. For other uses you must obtain permission from the rights-holder(s) directly, unless additional rights are indicated by a Creative Commons license in the record and/ or on the work itself. This Thesis has been accepted for inclusion in WVU Graduate Theses, Dissertations, and Problem Reports collection by an authorized administrator of The Research Repository @ WVU. For more information, please contact researchrepository@mail.wvu.edu. 
Organic methods to control root rot of peas and spinach in north-central West Virginia

\section{Hannah Witten Schrum}

Thesis submitted to the

Davis College of Agriculture, Forestry, and Consumer Sciences

At West Virginia University

in partial fulfilment of the requirements for the degree of

Master of Science

in

Horticulture

Sven Verlinden, Ph.D., Chair

Jim Kotcon, Ph.D.

Lewis Jett, Ph.D.

Division of Plant and Soil Sciences

Morgantown, West Virginia

2008

Keywords: Root rot, Organic disease control, Solarization, Organic matter, Cover Crops, Transplanting 


\begin{abstract}
Organic methods to control root rot disease of peas and spinach in north central West Virginia
\end{abstract}

Hannah Witten Schrum

Root rot disease is a limiting factor in organic production of cool season crops for many growers in North central West Virginia. In attempt to control root rot and its devastating impact on crop stands we decided to study a number of environmental, cultural, and biological control methods. The purpose of this work was to study the effect of alterations of the seed environment on disease incidence (measured by crop emergence and survival 21 days after planting) and thereby define techniques which are suitable for small growers to adopt if they have root rot problems. We therefore explored four broadly defined methods of controlling the disease: the relationship between the amount of soil organic matter (OM) and disease incidence; the efficacy of soil pasteurization via solarization; the suppressive effects of cover crops on disease incidence; cultivation techniques and the influence of those techniques on the physical properties of the rhizosphere and disease incidence.

Neither high nor low fertility treatments had an impact on crop emergence. In addition, regression analysis indicated that there was no correlation between the amount of organic matter and emergence of either peas or spinach. Results from solarization field experiments showed a strong $(\mathrm{P}<0.05)$ positive effect of solarization on the emergence of peas and spinach. Experiments with cover crops/ green manures clearly illustrated that common cover crops such as buckwheat or fieldpea serve no purpose in suppressing root rot pathogens, at least not in the short term. In that particular experiment, control plots (those left fallow) supported the highest emergence rates for both pea and spinach. In terms of disease control, the method with the best results in controlling root rot was transplanting. In addition this method is more practical, reliable and produces consistent results compared to the variety of other techniques and influences this project investigated. 


\section{Acknowledgments}

I am very gracious for the funding made possible by the Hatch Act that made my graduate assistantship possible. In particular, thanks to Dr. Verlinden for believing in and supporting my potential as a graduate student. Endless thanks to Dr. Kotcon for his constant enthusiasm and encouragement. I am likewise indebted to several good folks whose patience and solid technical support was second to none- Evan Anderson, Marvin Clark, and particularly fellow MS students J.B. White and Victoria Gonzalez- muchisimo gracias!

The opportunity to pursue this degree afforded me many opportunities and lessons along the way. I can think of few things that have served as such a positive force for me...I am so thankful. 


\section{Table of Contents}

Abstract.......................................................................

Acknowledgments................................................................ii

Table of contents............................................................

List of Tables ..........................................................vi

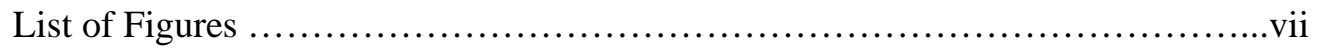

Chapter 1-Introduction and Literature Review

Root Rot................................................................

Soil Organic Matter and Disease Incidence...................................

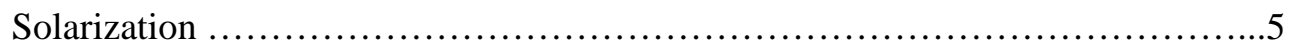

Cover Crops......................................................................

Cultural Manipulation and the Rhizosphere................................. 7

Overviews and Goals- Objectives.......................................10

Chapter 2-Materials and Methods

General................................................................11

Soil Organic Matter.....................................................12

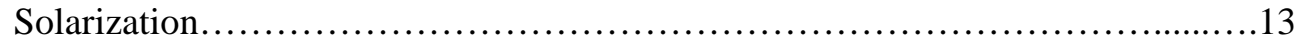

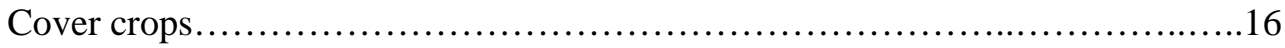

Cultural Manipulations......................................................17

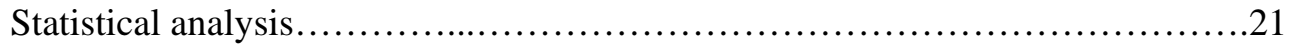

Chapter 3-Results

Soil Organic Matter..........................................................22

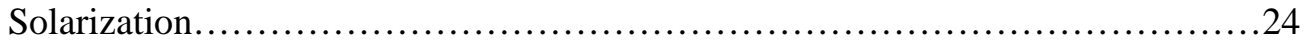

Cover crops.........................................................40 
Cultural Manipulations...................................................44

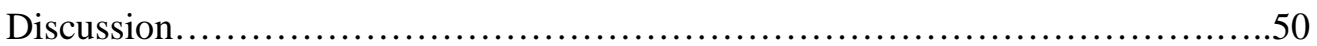

Chapter 5- Conclusions....................................................57

Appendix A-Summary of Field I solarization experiment.........................59

Appendix B-Summary of Field II solarization experiment.......................60

Appendix C-Summary of soil incubation in first lab experiment...................61

Appendix D-Temperature and moisture in averages under different cultural treatments...................................................62

Appendix E-Compost nutrient analysis.....................................63

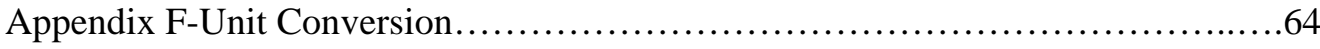

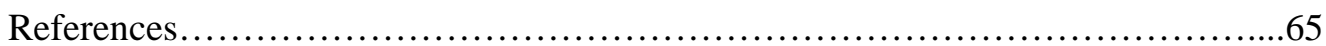




\section{List of Tables}

Table 1 Summary of crop emergence with \% of soil OM in high and low input plots...............................................................

Table 2 Average high and low temperatures in solarized soil and a control plot from 20 randomly selected days in

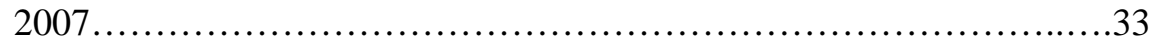

Table 3 Mean emergence of spinach and peas after 21 days in the fall 2006 and spring

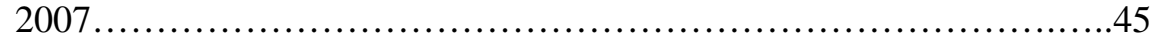




\section{List of Figures}

Figure 1 Soil profile of compost troughs show different volumes of compost and dimensions of the troughs....

Figure 2 Mean average emergence of peas and spinach in the fall (2006) after 0,4,or 8 weeks of solarization in the prior summer in Field I......................25

Figure 3 Mean average emergence of peas and spinach in the spring (2007) after 0,4,or 8 weeks of solarization in the prior summer in Field I..........................26

Figure 4 Mean average emergence of peas and spinach in the fall (2007) after 0,4,or 8 weeks of solarization in the prior summer in Field I .....................27

Figure 5 Mean average emergence of peas and spinach in the spring (2008) after 0,4,or 8 weeks of solarization in the prior summer in Field I ......................28

Figure 6 Mean average emergence of peas and spinach in the fall (2007) after 0,4,or 8 weeks of solarization in the prior summer in Field II.......................30

Figure $7 \quad$ Mean average emergence of peas and spinach in the spring (2008) after 0,4,or 8 weeks of solarization in the prior summer in Field II .......................31

Figure 8 The effect of soil incubation and duration on pea seedling emergence/survival in root rot infested soil..................................................35

Figure $9 \quad$ The effect of soil incubation and duration on spinach seedling emergence/survival in root rot infested

soil. ...

Figure 10 The effect of soil incubation at constant temperatures versus temperature fluctuations on pea seedling emergence in root rot infested soil.

Figure11 The effect of soil incubation at constant temperatures versus temperature fluctuations on spinach seedling emergence in root rot infested soil 39

Figure 12 Emergence of pea and spinach (after 21 days) when planted into soil treated with cover crop/green manure, cut and tilled into the soil at different intervals prior to planting.

Figure 13 Regression analysis of pea emergence in relationship to the dry weight of the cover crop .42

Figure 14 Regression analysis of spinach emergence in relationship to the dry weight of the cover crop........................................................

Figure 15 Mean emergence/survival of peas and spinach treated with Root Guardian, transplanted and control in fall

2007 
Figure 16 Mean emergence/survival of peas and spinach treated with Root Guardian, transplanted and control in spring

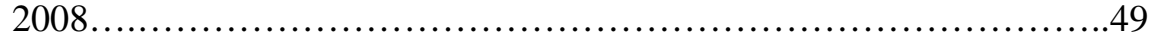




\section{Chapter 1-Introduction and Literature Review}

Root rot, seed rot and damping-off collectively represent a detrimental disease complex (hence referred to as root rot) which affects many horticulture crops. World wide, root rot can be a seriously detrimental disease in grain, legume, root, small fruit and leafy vegetable crops (Miller, 1995; Kumar, 1999; Bardin, 2004).The disease is marked by poor seedling emergence; infected seeds are soft, mushy and quickly deteriorate. Above ground, infected seedlings will show symptoms of lesions on stems and leaves. Often the stem is girdled by a necrotic lesion and the ensuing rot effectively cuts the seedling off at the soil. Roots are infected similarly. While numerous pathogens are recognized as culprits of root rot, the three primary pathogens identified by the Department of Plant Pathology at West Virginia University in this study are Pythium ultimum, Rhizoctonia solani and Fusarium spp. (Dr. James Kotcon, WVU, personal communication, 2006 and Dr. Yilmaz Balci, WVU, personal communication, 2008)

Pythium, Rhizoctonia and Fusarium are soil borne fungi - although it should be noted that Pythium spp have been re-classified as achlorophyllous brown algae under the Stramenopile kingdom (Patterson, 1989). However, for the sake of this research and ease of writing, Pythium will still be referred to as a fungus in this thesis. Pythium, Rhizoctonia and Fusarium are ubiquitous and persistent in many soil ecosystems, have broad host ranges, can display saprophytic as well as parasitic feeding habits, and use hardy physical dormancy structures (Hodges, 2003). Pythium spp have an optimal growth temperature of $64-75^{\circ} \mathrm{F}$ in addition to high soil moisture for zoospores to be motile and reach sprouting seeds. The sporangia as well as the oopspores persist in the soil as survival structures. Rhizoctonia solani is active in temperatures $70-86^{\circ} \mathrm{F}$ (it is more active in warmer end of that spectrum) and also needs a high amount of soil moisture to be active. It survives in the soil as sclerotia and hyphae, and when hosts are present 
for parasitism, the sclerotium or hyphae germinate and attack seedlings using infection pegs. The optimal growth temperature for Fusarium solani is $77-86^{\circ} \mathrm{F}$, but will develop at $64^{\circ} \mathrm{F}$ and above. F. solani infects emerging seeds below the soil via the stomata of the epicotyl, hypocotyls or upper taproot. The infection then spreads via the root system (characteristics reddish brown streaks), but is rarely isolated from above ground portions of the seedling. Fusarium forms chlamydospores as dormant/survival structures (Kraft and Pfleger, 2001).

Contributing to the pathogenicity of disease, Pieczarka (1978) described that the three genera of pathogens can also as act synergistically in inflicting disease (or affecting hosts). Although many crops can be afflicted with Pythium, Rhizoctonia, and/or Fusarium, the host crops plagued with root rot in this study are spinach (Spinacia oleracea) and garden pea (Pisum sativum). An extensive literature review did not reveal any root rot resistant variety for either spinach or pea.

Conventional treatment of root rot relies on fungicidal seed treatments such as metalaxyl or mefanoxam (Hodges, 2003). In cases of severe infestations, methyl bromide (MBr) fumigation of (commercial) fields was typical before a federal ban on $\mathrm{MBr}$ was imposed with the phase out completed in 2005 (Duniway, 2002). However recent concerns about the environmental impact of these chemicals, and moreover in response to the growing demand for certified organic produce, new solutions for disease control must be identified. Prevention is often cited as the best recommendation against root rot (Miller, 1995; Hodges, 2003). But even with proper crop rotation, good drainage, and other field management techniques some growers still have soil plagued with root rot pathogens. Currently, growers interested in maintaining certified (organic) crops have few options in adequate disease management short of resigning from pea and/or spinach harvests (Williams-Woodward et al., 1997). For many growers in North central West Virginia obtaining a marketable crop of either peas or spinach is nearly impossible due to poor seedling stands caused by root rot (Dr. Verlinden, WVU, personal communication). Thus the purpose of this study was to test and develop methods for 
controlling root rot of pea and spinach that are appropriate for small growers who wish to adhere to organic standards. We, therefore, explored four broadly defined methods of controlling the disease: the relationship between the amount of soil organic matter (OM) and disease incidence; efficacy of soil pasteurization via solarization; the suppressive effects of cover crops; and cultivation techniques and the influence of those techniques on the physical properties of the rhizosphere and disease incidence.

\section{Soil Organic Matter and Disease Incidence}

The health and vigor of a crop closely corresponds to the health and fertility of the soil in which it grows (Sullivan, 2004). Two standard practices in managing soil fertility in sustainable agriculture and especially in organic production include the use of green manures and/or the application of compost. While cover crops can provide numerous benefits to the soil, they are notably advantageous for the added fertility and organic matter they supply when added as green manure to the soil. Despite the fact that the nutritional composition and biomass vary greatly depending on the type of cover crop used, the use of any cover crop is considered a baseline technique in organic soil fertility management (Manici et al., 2004). The application of mature composts as a way to restore nutrients to the soil is also a classic method of managing soil fertility. Compost applications improve soil structure, and chemical and biological properties (Abbasi et al., 2002). In recent decades science has recognized the high populations of microbial biomass, endemic to mature compost, as having additional benefits to the soil environment. Abbasi et al. (2002) and Boehm (1993) both found plant disease reducing effects provided by the application of compost amendments. Though the mechanisms are not completely understood, the theory is that increasing the diversity and population of microbes leads to a rhizosphere which is less conducive to the development and establishment of some plant diseases (Sullivan, 2004). The dynamics of the soil environment and microbial interactions within the rhizosphere are complex and constantly changing. In an agro-ecosystem where the natural balance and cycles of soil are disrupted and manipulated by farming practices, the result can create a soil 
environment that is conducive to crop disease (Altieri, 1999). Oppositely, soils described as suppressive, produce healthy crops despite the existence of favorable conditions for disease to affect plants (Sullivan, 2004). Specifically the term fungistasis may be implied here, which indicates the condition found when the present fungal spores in soil are not activated —or are unable to germinatedespite the presence of favorable environmental conditions (Lockwood, 1964). The degree to which soil is suppressive to disease is relative and can be natural or induced (Schroth and Hancock, 1982).

In order to study suppressive or conducive properties of soils in terms of incidence of root rot disease and a possible link to soil organic matter (OM) content, we turned to an on-going study at the West Virginia University Plant and Soil Science Farm. The study, which has been underway since 2000, examines the differences in yields of market garden crops (including spinach and garden pea) grown under low and high fertility treatments. Low fertility treatments plots have received a green manure of a rye-vetch cover crop treatment each spring since 2000. Plots receiving high fertility treatments were fertilized with a dairy manure compost at 10 tons per acre in addition to the green manures applied to the low input treatment. We observed and examined the correlation between soil $\mathrm{OM}$ and root rot incidence in the pea and spinach crops that are part of this ongoing experiment in order to develop better understanding of the relationship between soil fertility, OM, green manures, compost applications and root rot incidence.

\section{Solarization}

Solarization is a technique that utilizes the intense solar radiation trapped by clear plastic during summer (in temperate climates) to effectively pasteurize field soils. This process is initiated in the weeks or season before planting and can take 2 to 9 weeks to achieve pasteurization, depending on the pathogens present and the soil temperatures that can be reached (Pinkerton, 2000). In most applications of this method bare soil is irrigated and then tarped with clear polyethylene plastic. The sides of the plastic are buried such that the tarped field is sealed in order to retain and maximize solar 
heating of the soil. Solarization has been used successfully in reducing or eliminating various soil pathogens and weeds across the globe (Hagan, 2000; Pinkerton et al., 2000). In theory, heat pasteurization targets mesophyllic organisms, or plant pathogens, while leaving more heat tolerant beneficial organisms to survive (Pinkerton et al., 2002; Katan, 1981). Furthermore, solarization has received more attention in recent years as it is seen as a viable alternative to disease control achieved by methyl bromide or other chemical treatments (Pinkerton et al., 2000 and 2002).

The method by which solarization is effective on plant pathogens is not fully understood (Katan, 1981). Dyer et al. (2000) and Katan (1981) generated models that can predict thermal death rates of pathogens under solarization. The term thermal death rate describes the time it takes at a given temperature to produce fatal affects on a pathogen population. Pathogen death rates are both time and temperature dependent. However, the exact mechanism by which solarization subdues or kills the pathogens is unknown. Several hypotheses have been formulated including i) death by direct heat damage ii) death by accumulated heat damage iii) induced weakening and thereby increased susceptibility to pathogens and iv) death by soil volatiles (Dyer et al., 2006; Katan, 1981).

In order to determine if the root rot complex we have encountered can be controlled by a solarization treatment we used a field experiment to explore the efficacy of solarization as a means of disease control in West Virginia. In order to understand the mechanism behind the efficacy of solarization in controlling root rot, we also investigated, in a controlled laboratory and greenhouse settings, whether high temperatures alternated with low temperatures were more effective than constant high temperature in reducing disease incidence. 


\section{Cover Crops}

Cover crops grown and turned under as green manure provide soils with increased nutrients, microbial activity, and in some cases disease suppression (Pinkerton, 2000). With a general movement away from chemical use in sustainable agriculture, a growing body of research is being devoted to the disease suppressing effects of cover crops turned green manure (Williams-Woodward, 1996). The relationship between disease suppression of specific pathogens, the fertility needs of the (vegetable) crop, and the cover crop is complex. So far there is no evidence of a single 'silver bullet' species of cover crop that is suppressive to a broad-spectrum of plant pathogens (Anon., 1998). Although root rot pathogens are difficult to eradicate due to their saprophytic nature, some research has indicated that oat, broccoli and field pea cover crops can decrease root rot incidence in subsequent crops. However, the decline in disease incidence seen in this body of research was only significant after five years (Anon.,1998). While certain cover crops can suppress some diseases due to volatiles released during decomposition, other cover crops can induce saprophytic pathogen populations thereby negating the likelihood of disease suppression (Pinkerton, 2000; Yulianti et al., 2006). In order to study the possibility of using cover crops to control the root rot complex on our farm we compared the disease suppressive efficacy of two cover crops that are currently used in soil management at WVU, buckwheat (Fagopyrum sagittatum) and field pea (Vigna unguiculata).

The time at which a cover crop is cut and allowed to decompose before planting a subsequent market crop is important in the attempt to control root rot disease (Davis and Nunez, 1999). Normally, it is advised to allow four to eight weeks after a cover crop is cut or a green manure is turned under in order to allow for adequate decomposition. However in north central WV, the window for planting cool season vegetables, such as peas and spinach, is so short that four to eight weeks would shorten the growing season beyond a useful time window for cool season cropping. As such, this trial evaluated the effects of two different cover crops as well as the effect of different time intervals (two weeks, one week, and day of planting) between the time of cutting down the cover crops and the time of planting the market crops (peas and spinach). 


\section{Cultural Manipulations and the Rhizosphere}

Critical to solving any plant disease problem is understanding the concept of the plant disease triangle. We therefore wanted to focus our efforts on the seed environment and variations in cultural techniques that could favor growth of the crop over development of the pathogens. We explored the efficacy of controling root rot by increasing both soil temperature and drainage; providing a physical barrier around the rhizosphere from the pathogen; introducing antagonistic microbial populations; and exploiting the seedlings' naturally induced resistance brought on by maturity.

Because peas and spinach are cool season vegetables, their optimal growing conditions (temperature of $55-75^{\circ} \mathrm{F}$ ) coincide with conditions that favor the growth of root rot pathogens. The two important environmental factors which impact soil fungi are soil temperature and moisture, with the latter having greater potential influence on the pathogenicity of the disease (Kumar et al., 1999). Research has shown that the pathogens in this study, are more destructive at lower temperatures and higher moisture than at higher temperatures and lower moisture (Kumar et al., 1999). Cultural management and techniques should therefore be geared towards creating high temperatures and low moisture. Ridge planting or the use of raised beds are a common recommendation for planting seeds (Hodges, 2003). Ridge planting commonly refers to a slightly raised seedbed, generally established on the ridges of a tractor tilled bed. The raised soil bed increases drainage and temperature, thereby optimizing conditions for seed germination and development.

Opposite from the convex seed bed created by ridge planting, seeds can also be planted into concave troughs of compost inlaid in the field (refer to Fig. 1). By utilizing compost as a seed bed, we postulated that drainage could be improved due to the porous nature of the compost. Warmer temperatures should also be realized due to the darker color of compost compared to the surrounding soil and therfore should absorb more sunlight. Importantly, by forming a physical barrier around the seed exudates, the compost environment may allow seedlings to develop beyond susceptibility of the 
pathogen (Mandelbaum and Hadar, 1990). Additionally, a potentially added benefit could be the direct increase in antagonistic microbial activity provided by the compost as mentioned in the previous section (Sullivan, 2004; Szchech et al., 1993). Complicating this part of our work is that the variation in microbial diversity and density between types and batches of compost is poorly understood (Sullivan, 2004). We therefore decided to compare two very different composts in this study, vermicompost and dairy manure compost. Vermicompost is a unique compost created by earthworm castings. It has been under recent study and has been hailed as having an extraordinary source of microbial activity (Anastasi et al., 2005; Edwards, 1998). Several studies have demonstated the suppressive effects of vermicompost on a number of soil born pathogens, including Pythium and Rhizoctonia (Szcech et al., 1993; Rivera et al., 2004). The other compost we wanted to test was a locally made dairy compost. It is currently used in field managment at the WVU farm.

The concept and application of biological control of plant pathogens is now a growing interest to both research institutions and industry. The broad spectrum biocontrol effects attributed to soil organic matter has in some cases been refined to single beneficial species and some of these are presently marketed in the form of seed treatments and soil drenches. Trichoderma spp. is one such genus of fungus that has been identified and commercially cultured as an antagonist to Pythium, Rhizoctonia, and Fusarium (Bjorkman, 1999). This fungus attaches to pathogenic fungi hyphae, and then degrades the cell walls by releasing a chitnase enzyme (Hodges, 2003). However, despite the idyllic appeal of controlling root rot disease with specific commercially adapted biocontrols, the reports on the efficacy of these solutions are mixed (Dr. James Kotcon, WVU, personal communication, 2006; and Katan, 1981). This may be due to the vast complexity of the microbial dynamics in the rhizospheric ecosystem which are not yet fully understood (Handelsmann and Stab, 1996). Thus as a portion of the study evaluated the efficacy of a soil drench, Root Guardian (active ingredient: Trichoderma harzianum) which is marketed to organic growers as a way to control root rot. 
In one additional attempt at altering the disease triangle, we changed the host environment by planting our crops as transplants rather than direct seeding them in the field. Although peas are traditionally a direct-seeded crop in the United States, transplanting pea seedlings from flats into field soil is a common practice observed in Dutch and Belgian horticulture as part of season extension methods (Dr. Sven Verlinden, personal communication, WVU, 2006). In this approach, seeds are planted in flats and allowed to grow as clumps of 4-6 plants. They are placed in the field as clumps at a spacing that represents the equivalent of seeds normally planted per foot. Since the seedlings are developed well enough before they are transplanted (usually 10-14 days, or until seedling shows 3-4 sets of true leaves), they are beyond the most vulnerable stage of susceptibility to root rot pathogens (Hodges, 2003).We compared the efficiency of this method to the direct seeding methods as described above. We also extended this method to spinach production. 


\section{Goals:}

This research explored the relationship between root rot disease incidence and a multitude of variables in soil and planting conditions. The ultimate goal of my research was to understand the significance of soil organic matter and alterations in seeds bed conditions on disease incidence in pea and spinach crops. Furthermore we wanted to demonstrate and develop viable techniques that organic growers in West Virginia can adopt as part of integrated disease management of root rot of pea and spinach crops.

\section{Objectives:}

- Determine if a correlation exists between the amount of OM in soil and root rot disease incidence in pea and spinach crops.

- Determine the efficacy of soil solarization in managing root rot in north-central West Virginia.

- Test the efficacy of two commonly used cover crops and green manures in suppressing root rot pathogens.

- Determine the effect of a variety of cultural techniques on root rot disease incidence. 


\section{Chapter 2-Materials and Methods}

\section{A. Overview:}

In order to better understand methods of root rot disease management in organic farming systems four primary experiments were initiated on the WVU Organic Farm in the 2006 through 2008 growing seasons. Experiment one was designed to study the effect of organic matter on root rot incidence. Experiment two was designed to demonstrate solarization as a method to pasteurize field soil of root rot. Experiment three tested the use of specific cover crops/green manures as root rot disease suppressive amendments. Finally experiment four tested the effect of a variety of cultural techniques on increasing crop stands where root rot is prevalent.

\section{$\underline{\text { A.1 Field Site }}$}

All field experiments were carried out on the West Virginia University Organic Farm located in Morgantown, WV (USDA zone 6a). The WVU Organic Farm has been certified organic since 2003 and all experiments described in this section complied with USDA organic standards, rules, and regulations. The farm is located on Route 705, just west of the intersection with the Mileground in Morgantown. The latitude of Morgantown is 39.629N. The longitude is $-79.956 \mathrm{~W}$. Research for this project was carried out in and near the market garden (MG) plots which are established as part of a long term high versus low input fertility study. The soil in these research plots is a moderately well drained silt loam in the Tilsit series and is further described as fine-silty, mixed, semiactive, mesic Typic Fragiudults. The parent material is a siltstone or fine-grained sandstone. This site was chosen because it had consistent problems with root rot. The pathogens were identified as Pythium ultimum var. ultimum, Rhizoctonia solani, and Fusarium sp.

\section{A. 2. Plant Material}


Two vegetable crops, spinach and pea, were used to study biological and cultural methods for root rot control. Spinach (Spinacia oleracea 'Whale F1') seeds were purchased as certified organic seed from Johnny’s Seeds (Winslow, ME), while the garden peas (Pisum sativum 'Oregon Giant') were purchased from Seeds of Change (Santa Fe, NM). Seeds for the cover crops/green manure experiment (see below, section E) were buckwheat (Fagopyrum sagittatum) from Fedco (Waterville, ME) and untreated (non-organic) field pea (Vigna unguiculata) from a local seed supplier (Southern States, Morgantown, WV). Dairy compost was added to all plots, except for low input market garden plots, at a rate of 10 ton/acre in early March of each year. Hand watering was administered when rainfall was not sufficient. Plots were tilled once two weeks before planting and again directly before planting. Unless otherwise noted the plots in all experiments were planted with two 4-foot rows of peas (6 seeds$\mathrm{ft}^{-1}$, planted 2 in deep); and 2 2-foot rows of spinach (10 seeds $\mathrm{ft}^{-1}$, planted 1 in deep). Seedling emergence/survival was recorded 10, 15, 21 days after planting for all experiments.

\section{B. Soil organic matter and root rot disease incidence}

\section{B.1. General}

In an ongoing study at the WVU Organic Farm researchers are investigating the effect of low versus high fertility management on crop productivity in an area called the market garden. The Market Garden (MG) consists of 32 plots. Eight plots each are planted with one of four common groups of garden vegetables (Solanacea, Cucurbits, Legumes, and Lettuce greens) in a 4 year rotation. In a complete randomized design the fertility of 16 of those plots is managed by incorporating a green manure of winter rye (Secale cereale L.)/hairy vetch (Vicia villosa ) as a soil amendment only. These plots are considered the low fertility treatment. The 16 high input treatment plots use the same green manure in addition to the yearly application of locally made dairy compost at a rate of 10 tons per acre. Since the inception of the experiment organic matter has increased in both the low and high input treatments. However, organic matter content of the high input plots has on average increased at a 
higher rate than the organic matter content of the low input plots (Childers, 2005 and Dr. Verlinden, WVU, personal communication).

\section{B.2. Organic matter content}

Soil samples were collected in late winter to early spring at depths of 0-3, 3-6, and 6-12 inches. Soil samples from each of the plots were analyzed for organic matter content using a Loss-on-Ignition method (Ben-Dor and Banin, 1989) which determines organic matter by the difference in soil weight measured before and after samples are heated for 16 hours in a muffle furnace at $752^{\circ} \mathrm{F}$.

\section{B.3 Measurements}

In order to study the effect of organic matter on root rot we recorded the emergence rate of peas and spinach at 10, 15, and 21 days after planting in each of the established legume and leafy crop market garden plots. For each crop there were 4 low and 4 high input plots to serve as replications in the experiment. The plots were planted with three 25 foot rows of peas and spinach in the legume and leafy crop plots, respectively. The ends were flagged in 4-ft sections for peas and 2-ft sections for spinach. These ends were planted as described previously. We then analyzed the relationship between soil organic matter content (described above) and seedling emergence.

\section{$\underline{\text { C. Solarization }}$}

\section{C.1 Field experiment:}

A 40x35ft plot that is under the same field management as described for the high-input plots of the MG (section B.1), and where root rot disease was prevalent in previous years, was tilled and prepared for solarization in June/July of 2006 and 2007, respectively. The experimental design for this particular experiment was a randomized block design allowing three replications of each treatment. The treatments included solarization for four weeks, and solarization for eight weeks and the control. 
We used clear 6 mill polyethylene plastic (Hummert International, St Louis, MO) to cover the soil. The soil was raked flat after tilling and watered to field capacity before covering the plots with the plastic. The edges of the plastic were buried under soil to obtain a seal on each plot/replication. The plots which were solarized for eight weeks were covered in mid-June. Four weeks later, the blocks receiving four weeks of solarization were covered. The control plots were left fallow for the duration of the eight weeks. Soil temperatures were monitored using WatchDog data loggers (Model 400, Spectrum Technologies Inc., Plainfield, IL) with sensors placed approximately 2 inches below the soil. Seeds were sown on the same day at the end of each of the 4 and 8 week solarization treatments. Emergence and survival counts were recorded at 10, 15 and 21 days after sowing. After the experiment the field was planted with a rye/vetch cover crop following current field management practices in the market garden area of the organic farm. In spring 2007, in order to evaluate any carry-over effect of the previous summer's solarization treatments, the same plots were re-planted (tilling was done in such a way to minimize contamination between plots) in the manner described above and seedling emergence/survival was again recorded. The solarization was repeated in the summer of 2007 so data were collected in fall 2007. Also the evaluation of any possible carry-over effect was repeated in spring 2008. In June of 2007 a replicate of the above experiment was added in an adjacent plot above the MG to help determine if similar results could be repeated in a separate plot. The second solarized plot was evaluated in fall 2007 and also in the spring of 2008 to determine what or if any carry-over effects the previous summer's solarization may have on suppressing root rot in spring crops of peas and spinach.

\section{C.2 Lab/greenhouse Experiment:}

After initial observations on the effect of solarization on emergence and plant stands, a secondary experiment was initiated to gather information on how solarization may positively affect seedling emergence and stands. Field soil was therefore extracted from the root rot infested plots in NovemberDecember 2007 and incubated at 86, 95, 104, and $113^{\circ} \mathrm{F}$. One set of soil was incubated at these 
temperatures for four weeks; the second set was incubated for eight weeks. The degree range with nine degree increments was designed to cover the range of temperatures observed in the field and to help us determine which combination of temperature and time exposure resulted in the highest disease control. For each temperature, 1 gallon of soil stored in paper bags was incubated for four and eight weeks. Water was added on a regular basis to keep the soil near field capacity in order to mimic the soil environment of the field solarization treatment. At the end of eight weeks, plug trays were filled with the soil and pea/spinach seeds were planted. A control was added which consisted of soil freshly excavated from the field. The field soil for the control was excavated on the same day the seeds were planted for the experiment. The plug trays were placed in the WVU greenhouse in a mist bed and seedling emergence was recorded 10, 15 and 21 days after planting. Based on the initial results of this experiment we continued to expand on the lab/greenhouse study by incorporating temperature combination to mimic the fluctuations in temperatures observed in the soil covered for solarization treatment in the field. In February 2008 we took more soil from root rot infested fields and incubated it at 86F, 104F, 122 degree F for eight weeks in order to repeat and more thoroughly illustrate the disease suppression we found in the first experiment. Additionally, we added treatments in which soil samples kept at these temperatures were moved from their respective temperatures (86F, 104F, 122 degree F) to a growth chamber at 68 degree F approximately every 9-12 hours. This temperature fluctuation was imposed to replicate the day-night temperature change which field soil and the pathogens would naturally be subjected to. This experiment was added to help elucidate the mode of action by which solarization diminishes pathogens. We postulated that solarization kills root rot pathogens by imposing extreme stress on them with exposure to high then moderate temperatures in only a matter of hours. The temperature fluctuation may be more harmful than merely high temperatures alone. 


\section{Cover crop/green manure experiment}

This experiment was designed to determine the possible disease suppressive effects of one or two cover crops (buckwheat or field pea) used as green manures. A field plot (50’x25'), known to be plagued with root rot pathogens, was subdivided into plots for a randomized block design experiment. This field has been continuously managed under high-input fertility for five years. (Refer to section B.1). Three blocks, each containing 6 treatments and a control were laid out for a total of 21 plots (3 replications x 6 treatments and a control). The first three treatments (Treatments 1-3) used field pea as a cover crop. The plots were tilled on the same day as planting the vegetable crops (treatment 1), one week prior to planting (treatment 2), and two weeks prior to planting the vegetable crops (treatment 3). Treatments 4, 5, and 6 followed the same pattern except that buckwheat was used as the cover crop. The control plots were left fallow until the vegetable crops were planted.

All cover crops were planted simultaneously on July 25, 2006 and cut down using a weed eater and subsequently tilled with a Mantis tiller (Mantis, Southhamppton, PA) two weeks before planting, one week prior to planting, and the day of planting both spinach and peas. The above ground biomass of one square foot of cover crop was gathered and measured for each replication and recorded as dry weight per square foot. Samples were collected before the beds were thoroughly tilled for planting. Biomass samples were placed in paper bags and placed in a drying oven at 200 degree F for one week before dry weight was recorded. The vegetable crops were planted on September 15, 2006 (refer to method as described in section A.2). Both crops were direct seeded and emergence/survival of spinach and pea seedlings was again recorded on day 10, 15, and 21 after planting. 


\section{E. Cultural Techniques:}

\section{E.1 General}

In order to test the effect of cultural methods geared towards establishing higher seed bed temperatures and lower soil moisture content -environmental parameters less conducive for root rot incidence - we designed an experiment to test alternative seed bed preparation techniques on pea and spinach emergence. In a plot adjacent to the previously described MG plots, an experiment incorporating a completely randomized block design was laid out with 5 treatments and a control allowing for three replications of each treatment. The plot received compost (10 tons/acre) in early spring and was treated similar to the high input plots in the market garden (see above). 


\section{E.2 Treatments}

The following treatments were established in each of the three previously described blocks:

1) Compost troughs (2 treatments: dairy manure compost and vermicompost)

In a prepared bed where soil was prepped by traditional rototilling after compost incorporation, rows were excavated of field soil to create a trough (Figure 1). The trough was subsequently filled in with either dairy (WVU animal science farm) or vermicompost (UNCO Industries. Racine, WI). The compost material that came from the WVU animal science farm contained a mix of dairy manure and leaf litter (approximate ratio 50:50). It was properly composted and aged on the WVU Organic Farm prior to use. The same compost used in this experiment has been used, since inception, on the MG experiments as one of the sources of fertilizer for the high input plots. The seeds were planted in the troughs such that they were encased within the compost and had no contact with the field soil. (The same planting techniques and dimensions were used as described in A.2.) Refer to figure 1.

Additionally, we compared the effects of the volume of compost/size of the trough used. Treatments with greater volume of compost were dug wider and deeper to allow for the increase in compost. The two volumes of soil used were $54 \mathrm{in}^{3} \mathrm{ft}^{-1}$ and $144 \mathrm{in}^{3} \mathrm{ft}^{-1}$., low and high volume troughs, respectively. 


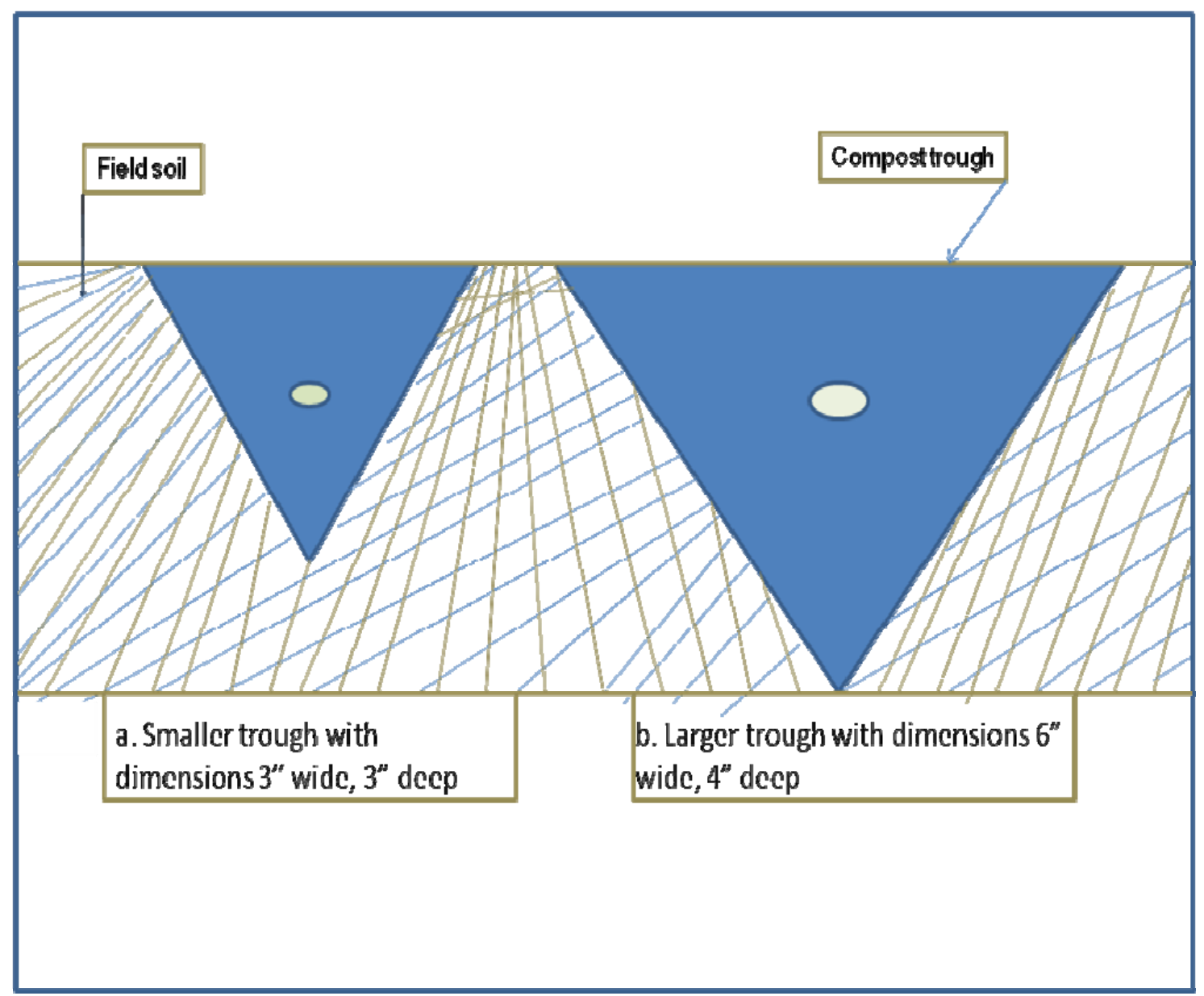

Figure 1. Soil Profile of compost troughs showing different volumes of compost and demensions of the troughs. Circles represent seeds planted within the troughs. 


\section{2) Ridge planting:}

In a prepared bed, field soil was mounded to create a convex-shaped seed bed. Two different heights of the ridge bed (3in. and 6in.) were compared to determine if any significant differences in seedling stand could be obtained by 1) establishing a ridge and if 2) increasing the ridge size and height leads to better seedling stands. In this case, the ridges which make up the rows were formed using a garden hoe and met the previously mentioned heights at the time of planting.

\section{3) Transplanting:}

In early March and late August of each year of my study seeds were sown in flats using organic growing media (made using one part WVU certified dairy compost, to two parts each of peat, and perlite) and allowed to develop for 10-14 days before being planted in the field (at the same time as seeds in the other treatments were sown). The flats were placed outside on wooden pallets to allow the seedling to develop. For fall trials the flats were placed under shade cloth to prevent scorching of the newly emerged seedlings. Flats were hand watered daily when rainfall was not sufficient. The seeds were planted in clumps, as prescribed by the previously described traditional western European season extension practice, such that 4-6 seeds represented one clump. Peas were transplanted with one clump per foot in four foot rows, for a total of four clumps or approximately 18 plants in each row. Spinach was transplanted at one clump every six inches in two foot rows, for a total of four clumps or approximately 20 plants per row.

\section{4) Control:}

Rows reserved for control observations were sown using traditional field planting methods in which seeds were directly sown into level rows. 


\section{E.3 Measurements}

Soil temperature and soil moisture were recorded in fall 2006 and spring 2007 trials using WatchDog data loggers (Model 400, Spectrum Technologies Inc., Plainfield, IL) placed in one of each

of the replicated treatments. Soil moisture and temperature measurements were recorded continuously at 3 hour intervals from the time of planting until the final field observation (21 days). Emergence/seedling survival was again recorded every 10, 15 and 21 days after planting.

\section{Statistical analysis}

In the first experiment in the market garden, data were analyzed using a simple one-way ANOVA for spinach emergence data in 2007 and a two-way ANOVA for pea emergence data in 2007 and 2008. In addition regression analysis was carried out to determine if a correlation exists between the percent OM observed in market garden plots and seedling emergence. For solarization field experiments a three-way interaction ANOVA was used. Greenhouse experiments were analyzed using a two-way ANOVA. Data from the cover crop experiment were analyzed using a simple one-way ANOVA. Means were separated by Tukey-Kramer HSD. In addition, simple linear regression analysis and analysis of co-variance was employed. Data from the cultural techniques in the final experiment were analyzed using a three-way ANOVA. Means were separated by Tukey-Kramer HSD. All statistical analysis was performed with the JMP statistic software package (JMP 3.1.5, SAS Institute. Cary, NC). 


\section{Chapter 3-Results}

\section{Soil Organic Matter and Disease Incidence}

Neither emergence of pea nor spinach was significantly affected by the fertility treatments (Table 1). No spinach emerged in 2008, and thus only 2007 data were reported. We did not observe a year effect on pea seedling emergence. The data were therefore reported using a two-way ANOVA. As in most of the following experiments, spinach emergence was much lower than that of the peas. Peas in the high fertility plots (mean \% OM 1.9) had slightly lower emergence (16\%) than peas in low fertility plots (mean \% OM, emergence $27 \%$ ). For spinach the high fertility plots had a mean \% OM of 2.28 with 7\% emergence, compared to low fertility plots (mean \% OM 1.8) with slightly higher emergence (11\%). Regression analysis indicated that there was no correlation between the amount of organic matter in the market garden plots and emergence of either peas or spinach.

All results reported in imperial units can be converted to SI units referring to appendix F. 
Table 1. Summary of crop emergence along with percentage of soil organic matter (OM) in high and low input plots. High= plots receiving dairy compost and green manure. Low=plots receiving only green manure.

\begin{tabular}{|c|c|c|c|}
\hline Crop & Fertility Treatment & Mean \%Emergence & Mean \% OM \\
\hline Pea* & high & 16 & 1.90 \\
\hline Pea* & low & 27 & 1.94 \\
\hline Spinach** & high & 7 & 2.28 \\
\hline Spinach** & low & 11 & 1.80 \\
\hline
\end{tabular}

*Pea emergence 2007 and $2008(\mathrm{p}=0.25)$, Two-way ANOVA.

**Spinach emergence $2007(\mathrm{p}=0.18)$. 


\section{Solarization}

\section{Field experiments I:}

Field I, which received solarization in summer 2006 and again in summer 2007, showed consistent results indicating a strong $(\mathrm{P}<0.05)$ positive effect of solarization on the emergence of peas and spinach. Furthermore, the data showed a significant increase in emergence with longer solarization periods. No cumulative effect was observed in plots treated with the same treatment two years in a row. Seed emergence in the fall seasons, directly after the soil had received the solarization treatments, was significantly greater than seed emergence observed in the following spring. For example, pea emergence was 62\% and 30\%, in fall 2006 and spring 2007, respectively (Fig. 2). In fall 2007 pea emergence was 62\% followed by a spring emergence of 43\% in 2008 (Fig. 4). In the spring seasons, the residual positive effect of solarization provided statistically significant increases in emergence of peas in both 4 and 8 week solarized plots.(Fig.3 and 5) In spring 2007 pea emergence was 16\%, 30\% and 10\% for the 4 week, 8 week and control treatments, respectively.(Fig. 3) For spinach the carry over effects of solarization were less prevalent and only those plots treated for 8 weeks continued to show significantly increased emergence compared to the control. No spinach emerged/survived in spring 2007, but in spring 2008 plots treated with 8 weeks of solarization had 15\% emergence compared with $<5 \%$ emergence in both the 4 week and control treatments. (Fig. 5) 


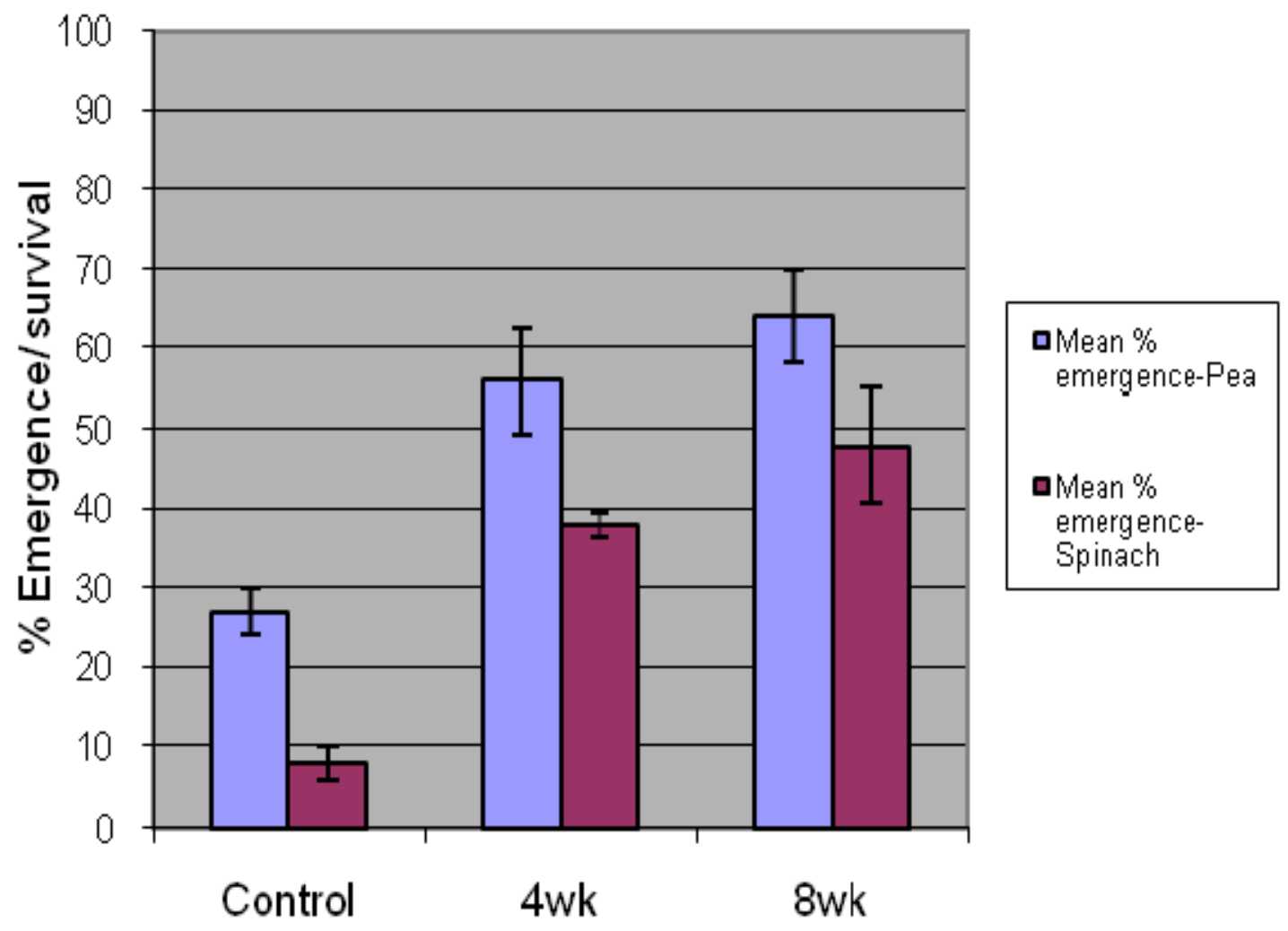

Figure 2. Mean average emergence of peas and spinach in the fall (2006) after 0, 4, or 8 weeks of solarization the prior summer in Field I. Error bars represent standard error of the means $(n=3)$. 


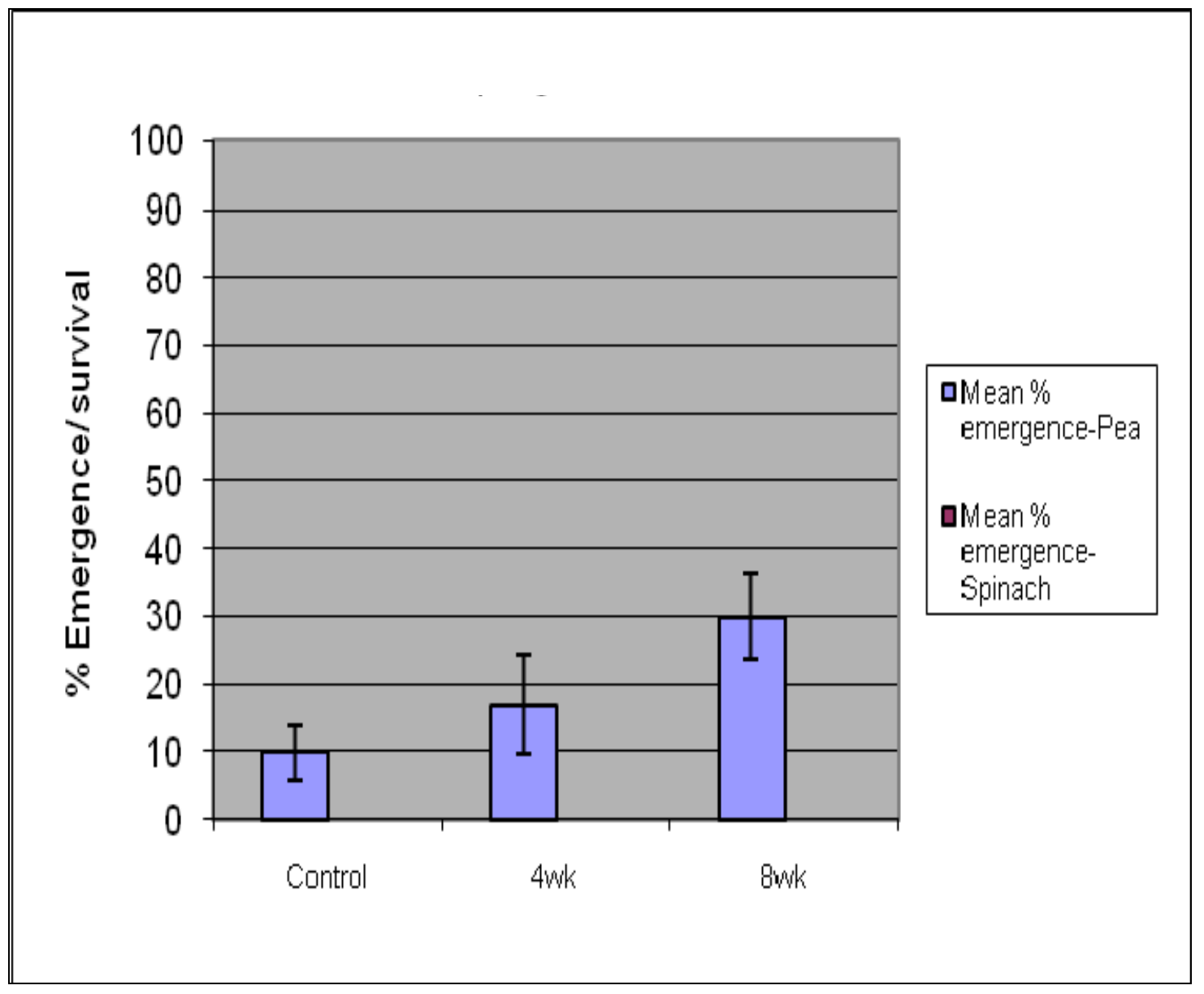

Figure 3.Mean \% emergence of peas and spinach in the spring (2007) after 0, 4, or 8 weeks of solarization the prior summer in Field I. No spinach emergence was observed in the plots in spring 2007. Error bars represent standard error of the means $(n=3)$. 


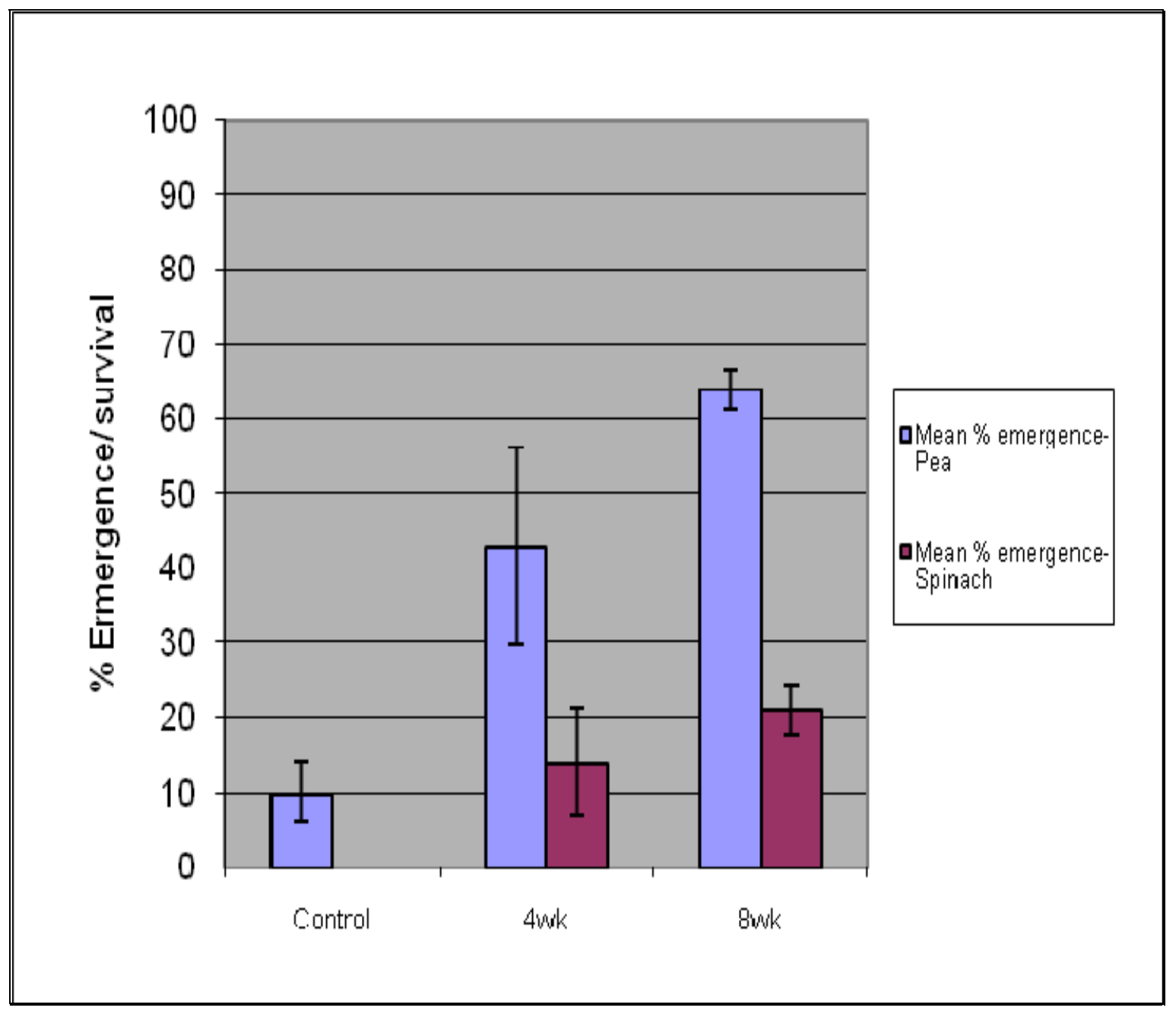

Figure 4. Mean \% emergence of peas and spinach in the fall (2007) after 0, 4, 8 weeks of solarization the prior summer in Field I. Error bars represent standard error of the means $(n=3)$. 


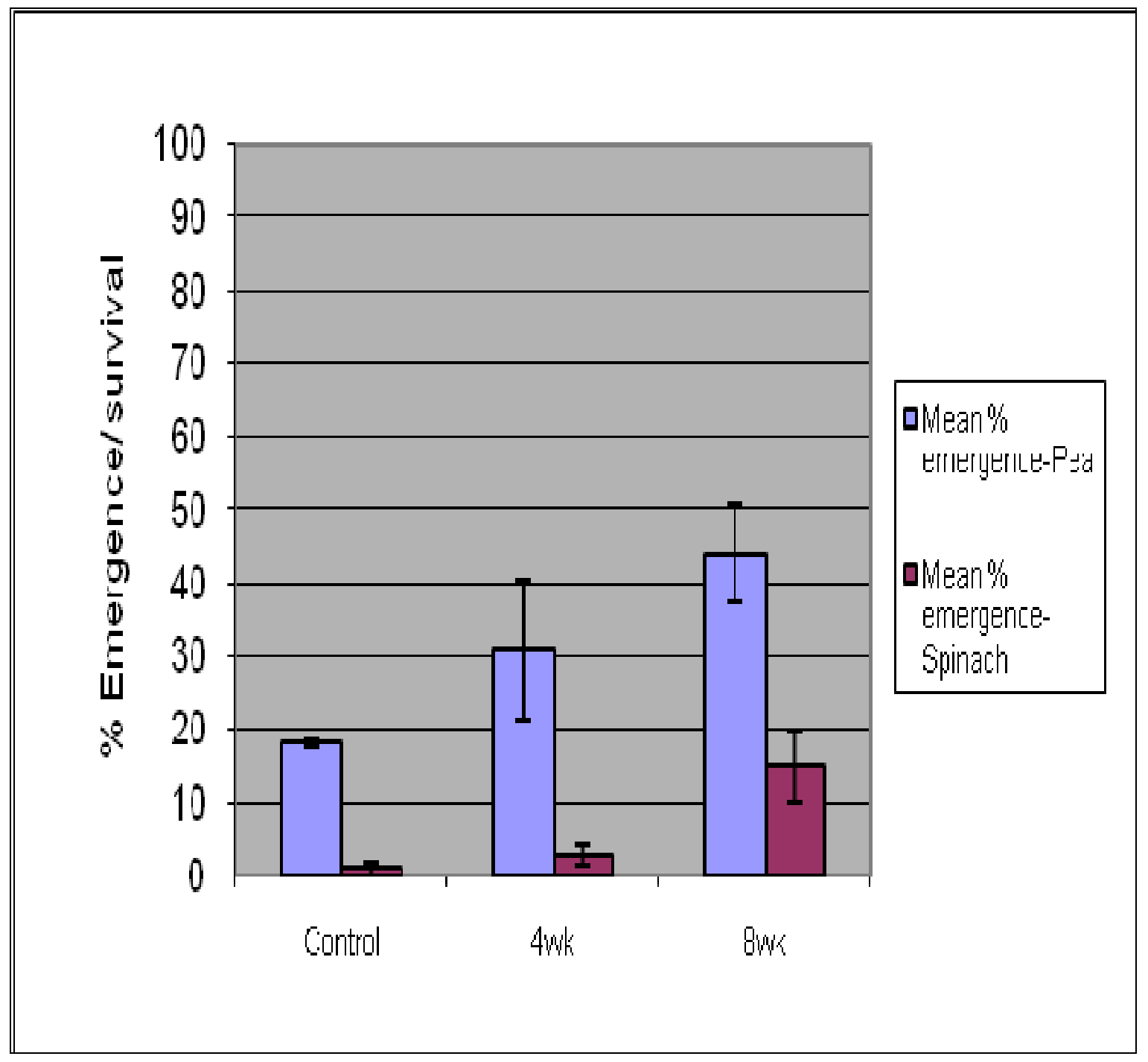

Figure 5. Mean \% emergence of peas and spinach in the spring (2008) after 0, 4, 8 weeks of solarization the prior summer in Field I. Error bars represent standard error of the means $(n=3)$. 
Field experiments II:

Field II, which received solarization only in summer 2007 showed there were some similar results as well as some different ones observed in Field experiment I. The data again indicated a statistically significant $(\mathrm{P}<0.05)$ improvement in crop emergence after solarization for both peas and spinach. As in Field I, plots treated for eight weeks showed the highest level of emergence when compared to the control and the plots solarized for four weeks. Pea emergence followed the same trend as found in Field experiment I. That is, emergence was greatest in solarized plots in the fall while in the same plots emergence was reduced in the following spring but still higher than the control. Pea emergence improved from $25 \%$ in control plots to $67 \%$ and $68 \%$ in plots solarized for 4 and 8 weeks, respectively. In the following spring, pea emergence (30\% and 35\% for 4 week and 8 week solarization, respectively) was reduced from that in the fall but still statistically greater than pea emergence in the control plots (14\%). Solarization was more effective in enhancing the emergence of peas than spinach. Even in plots treated with 8 weeks solarization, which supported the highest emergence in both crops, peas had 68\% emergence compared to 5\% spinach emergence in the fall; in the spring peas still had greater emergence (36\%) than spinach (13\%). However results differed from those of Field experiment I in that in Field experiment II, the emergence of spinach showed improvements in the spring season $(12 \%$, $13 \%$ and $<5 \%$ for 4 week, 8 week, and control, respectively) over the emergence ( $<5 \%, 5 \%$ and $<5 \%$ for 4 week, 8 week and control, respectively) observed in the previous fall season (Figures 6 and 7). 


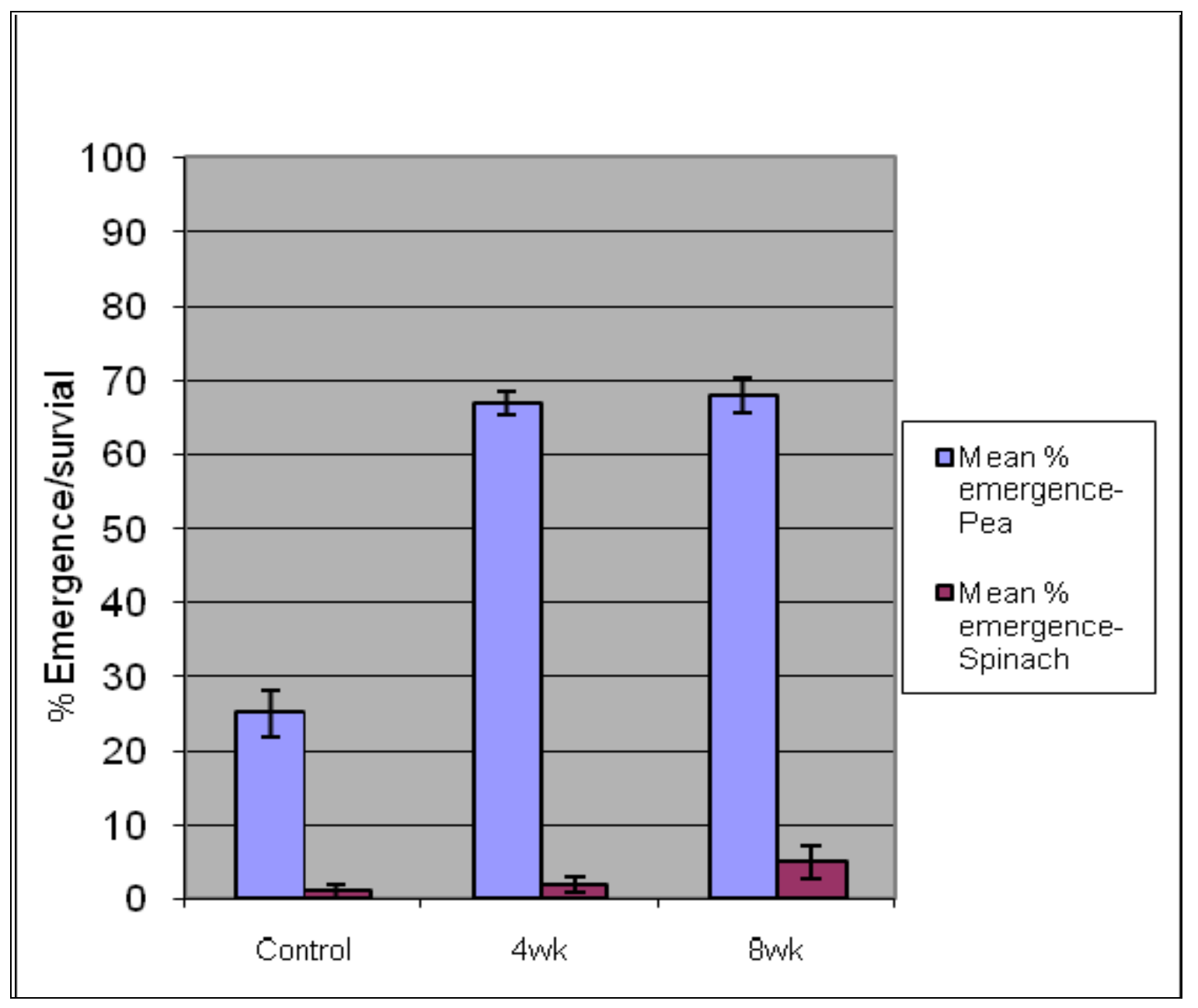

Figure 6: Mean \% emergence of peas and spinach in the fall (2007) after 0, 4, 8 weeks of solarization the prior summer in Field II. Error bars represent standard error of the means $(n=3)$. 


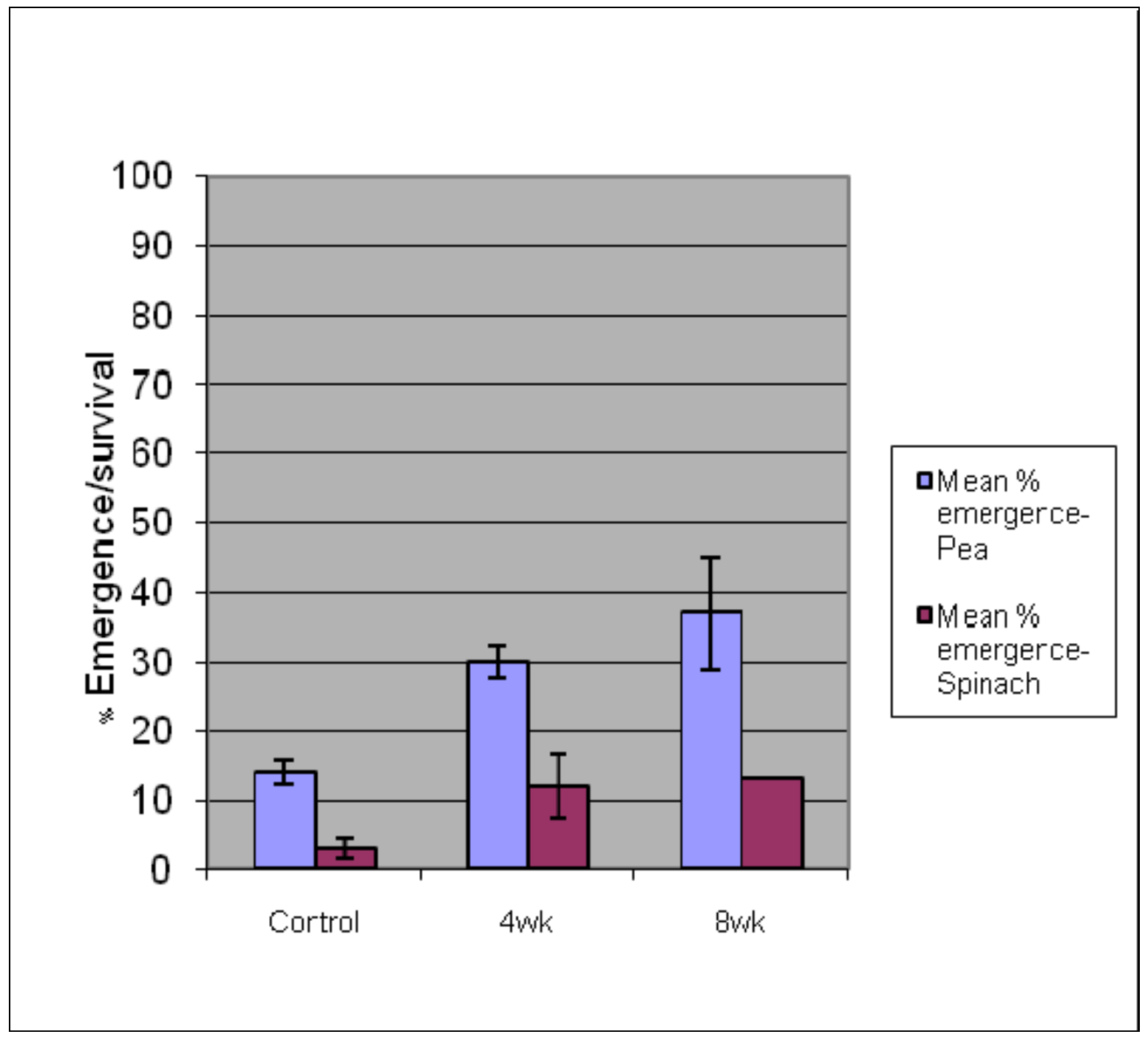

Figure 7. Mean \% emergence of peas and spinach in the spring (2008) after 0, 4, 8 weeks of solarization the prior summer. Field II. Error bars represent standard error of the means $(n=3)$. 


\section{Soil Temperature}

Data loggers recorded soil temperature for the duration of the eight weeks of the experiment. Table 2 is a summary of randomly selected days to show temperature differences between a solarized plot and a control plot. For the 20 day sampling represented here, the high temperature averaged $99^{\circ} \mathrm{F}$ and $77^{\circ} \mathrm{F}$ for the solarized and control plots, respectively. The low temperature averages for those same randomly selected days was $82^{\circ} \mathrm{F}$ and $74^{\circ} \mathrm{F}$ for the solarized and control plots, respectively. Based on these averages, the solarized plots experienced temperature differences of $17^{\circ} \mathrm{F}$ between the low and high temperatures. The temperatures recorded in the control plots was more constant and only differed on average by $3^{\circ} \mathrm{F}$ between low and high temperatures. The solarized plots reached a maximum of $114^{\circ} \mathrm{F}$, while the maximum temperature recorded in the control plot was $85^{\circ} \mathrm{F}$. 
Table 2. Average high and low temperatures $\left({ }^{\circ} \mathrm{F}\right)$ in solarized soil and a control plot from 20 randomly selected days in 2007. High temperatures represent an average of temperatures recorded between 11:00am and 5:00 pm. Low temperatures represent an average recorded between 11pm and $5 \mathrm{am}$. Thermocouples were placed 2 in. below the surface.

\begin{tabular}{|c|c|c|c|c|}
\hline Date & High , solarized & Low, solarized & High, control & Low, control \\
\hline 6/20/2007 & 96.1 & 77.8 & 77.2 & 71.3 \\
\hline 6/23/2007 & 98.4 & 77.8 & 74.4 & 70.3 \\
\hline $6 / 25 / 2007$ & 100.6 & 83.0 & 77.9 & 75.3 \\
\hline 6/29/2007 & 83.4 & 75.3 & 76.9 & 73.2 \\
\hline 6/30/07 & 100.2 & 78.1 & 75.7 & 69.7 \\
\hline 7/4/07 & 92.8 & 80.7 & 75.3 & 72.7 \\
\hline $7 / 5 / 07$ & 79.0 & 74.6 & 71.5 & 70.1 \\
\hline 7/8/07 & 107.4 & 85.6 & 79.0 & 74.1 \\
\hline 7/9/07 & 109.1 & 87.2 & 80.9 & 76.2 \\
\hline 7/10/07 & 108.0 & 87.6 & 82.0 & 77.2 \\
\hline 7/21/07 & 97.8 & 77.8 & 71.6 & 68.4 \\
\hline 7/25/07 & 101.0 & 80.9 & 74.3 & 71.1 \\
\hline 7/28/07 & 102.0 & 84.5 & 76.2 & 74.3 \\
\hline 7/30/07 & 100.6 & 82.9 & 77.9 & 75.1 \\
\hline 8/1/07 & 105.9 & 86.1 & 78.3 & 75.5 \\
\hline $8 / 2 / 07$ & 108.5 & 87.9 & 79.7 & 76.5 \\
\hline 8/5/07 & 83.9 & 79.2 & 75.7 & 73.9 \\
\hline 8/8/07 & 98.0 & 83.2 & 81.1 & 77.1 \\
\hline 8/9/07 & 97.2 & 81.6 & 80.4 & 75.5 \\
\hline 8/12/07 & 102.4 & 85.6 & 79.0 & 75.7 \\
\hline 8/13/07 & 101.2 & 82.7 & 79.3 & 73.4 \\
\hline Averages: & 98.7 & 81.9 & 77.3 & 73.6 \\
\hline
\end{tabular}




\section{Greenhouse experiments:}

I. In the first greenhouse experiment where soil was incubated for either four or eight weeks at temperatures ranging from 86 to $122^{\circ} \mathrm{F}$, both temperature and number of weeks in incubation significantly affected emergence $(\mathrm{P}<0.001)$. Emergence increased substantially the higher the incubation temperature of the soil. But the longer period of incubation combined with temperature showed the greatest effect on emergence. Only soil incubated at temperatures of 113 and $122^{\circ} \mathrm{F}$ for eight weeks showed a statistically significant impact on emergence. The effect was more pronounced in spinach (Fig. 9) than in peas (Fig. 8) $(\mathrm{P}=0.0003)$. All soil incubated for four weeks, regardless of the temperature, provided no improvement in seed emergence. 


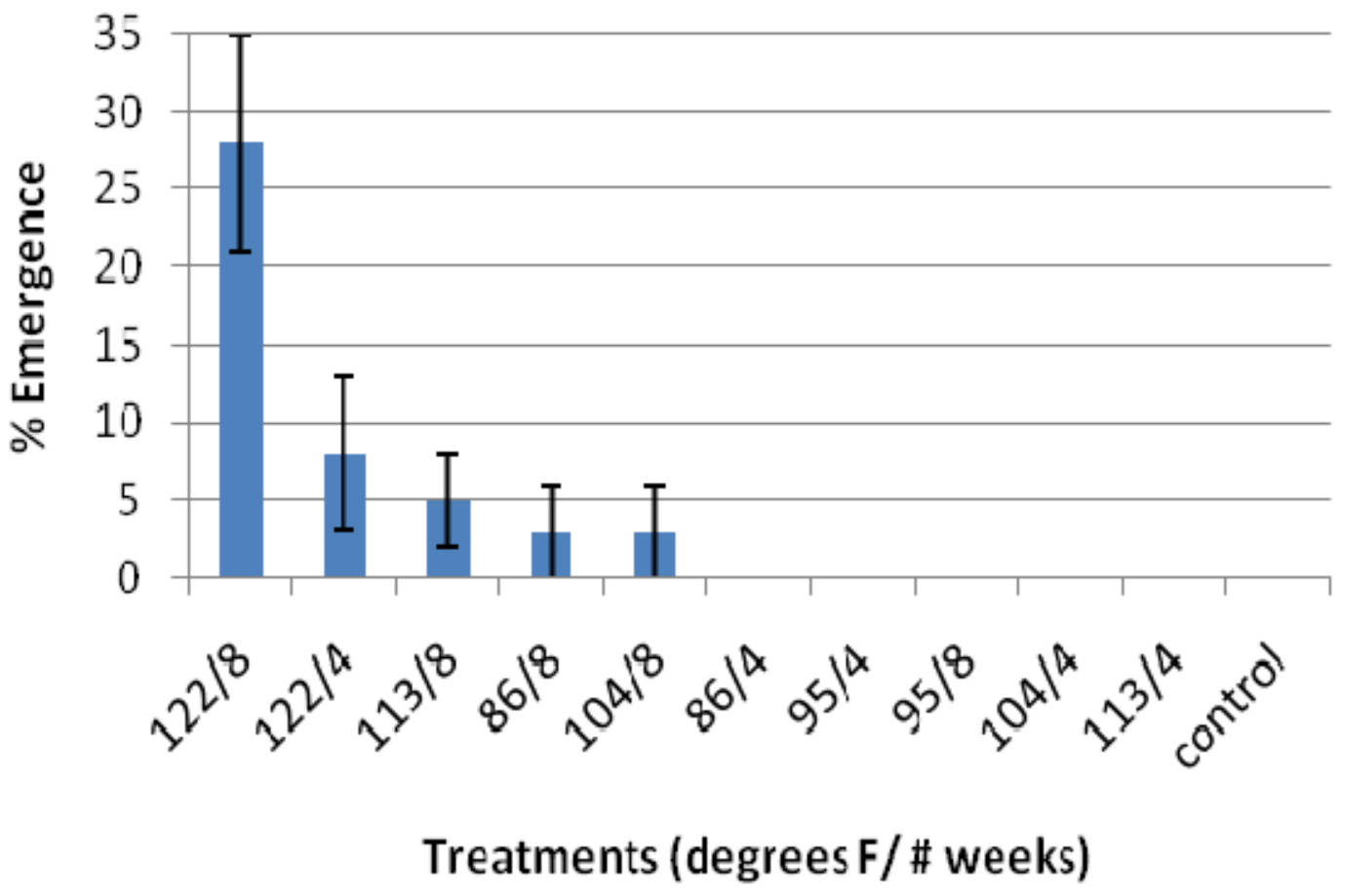

Figure 8. The effect of soil incubation temperatures and duration on pea seedling emergence/survival in root rot infested soil. Treatments are given in ${ }^{\circ} \mathrm{F} / \#$ of weeks and are shown in descending order of the amount of seed emergence realized after 21 days. Error bars represent standard error of the means $(n=3)$. 


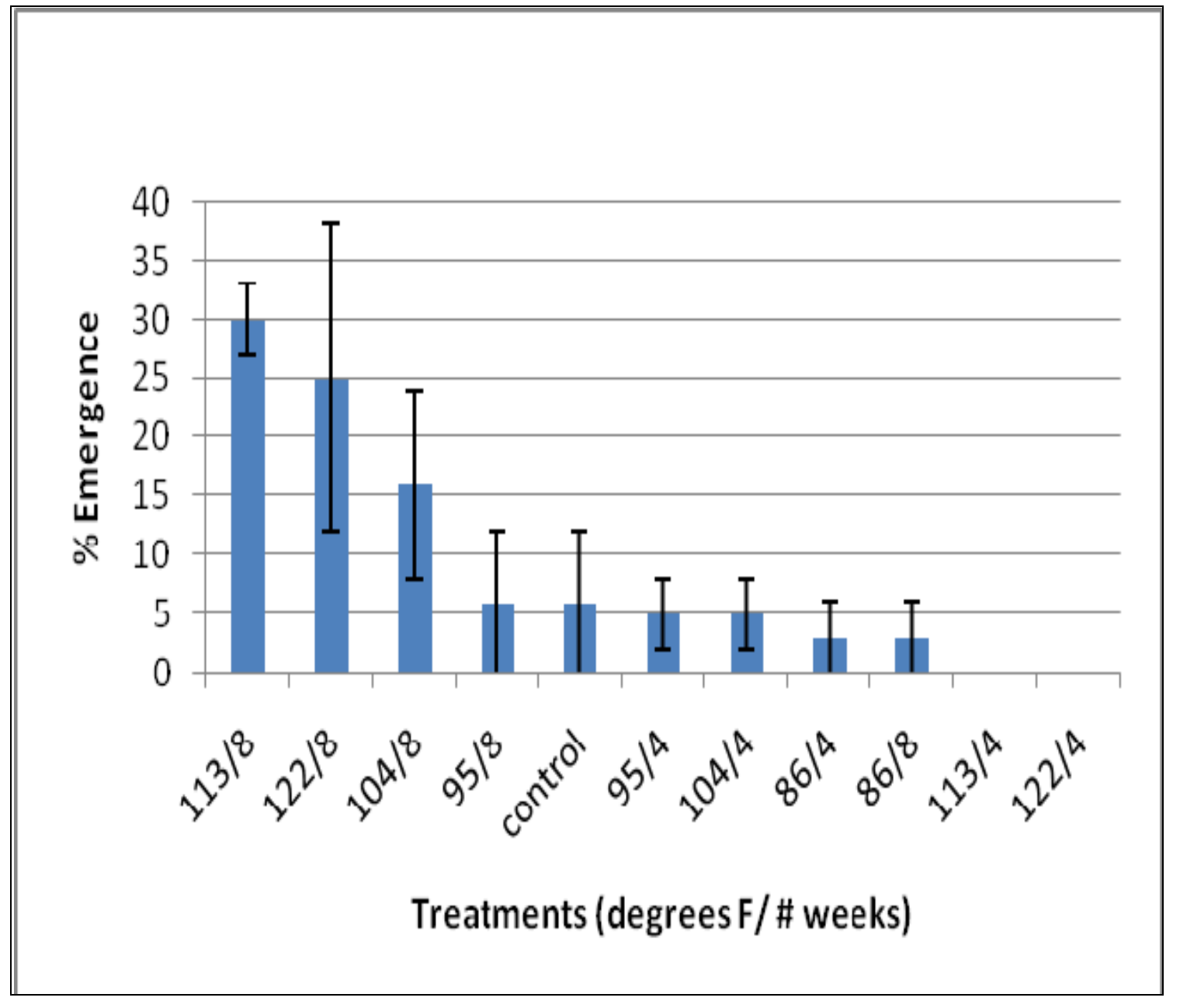

Figure 9. The effect of soil incubation temperatures and duration on spinach seedling emergence/survival in root rot infested soil. Treatments are given in ${ }^{\circ} \mathrm{F} / \#$ of weeks and are shown in descending order of the amount of seed emergence realized after 21 days. Error bars represent standard error of the means $(n=3)$. 
II. The second greenhouse experiment in which seeds were grown in soil that had either been incubated at a constant temperature $\left(86^{\circ} \mathrm{F}, 104^{\circ} \mathrm{F}\right.$, or $\left.122^{\circ} \mathrm{F}\right)$ or in soil that was incubated at alternating high and low temperatures $\left(86-68^{\circ} \mathrm{F}\right.$; $104-68^{\circ} \mathrm{F}$; or $\left.122-68^{\circ} \mathrm{F}\right)$, showed a similar trend of higher seed emergence in soil incubated at higher temperature. Analysis showed that there was a significant crop effect, a significant treatment effect, and a significant two-way interaction between crop and treatment effects. In peas, the ' $122-68^{\circ} \mathrm{F}$ ' treatment showed higher emergence than the other treatments, but not significantly higher than the control (10\% emergence vs. 3.33 $\%, \mathrm{P}<0.12$ ). See figure 10 . As in the previous greenhouse experiment the effect was more pronounced in spinach than in peas. In spinach, the emergence in the control treatment $(2.5 \%$ emergence) was significantly less than the spinach emergence in the $86,104-68,122$, or $122-68^{\circ} \mathrm{F}$ treatments. See figure 11 . The only treatment in which the $x-68^{\circ} \mathrm{F}$ combination was different from the constant temp was observed in peas (Fig.10). In peas the $122-68^{\circ} \mathrm{F}$ treatment showed higher emergence than the $122^{\circ} \mathrm{F}$ treatment. In spinach however the constant $86^{\circ} \mathrm{F}$ treatment resulted in higher emergence than the $86-68^{\circ} \mathrm{F}$ treatment (Fig. 11).

All results reported in imperial units can be converted to SI units referring to appendix F. 


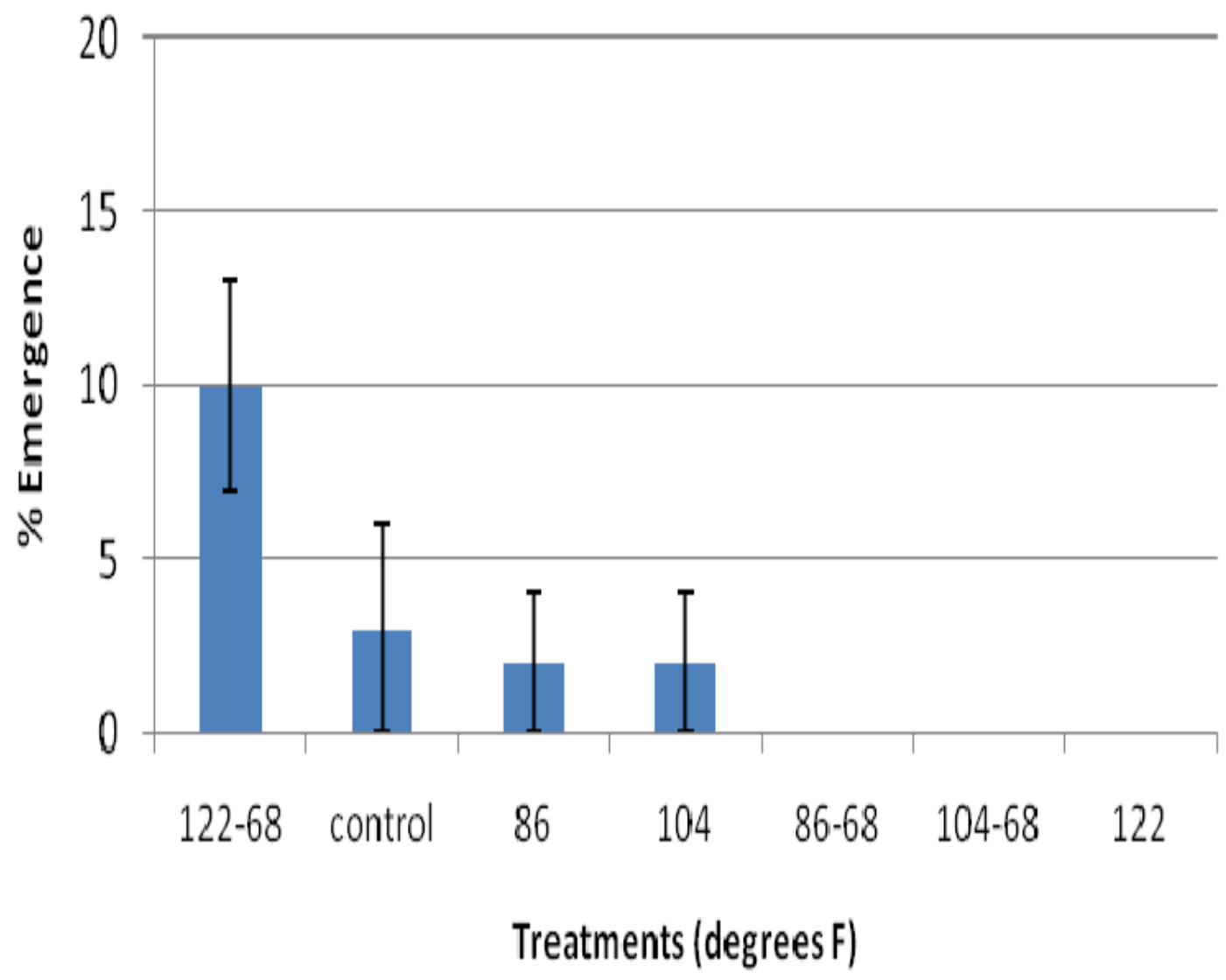

Figure 10. The effect of soil incubation at constant temperatures versus temperature fluctuations on pea seedling emergence/survival in root rot infested soil. Treatment numbers are ${ }^{\circ} \mathrm{F}$ (all treatments lasted for eight weeks). Hyphenated numbers indicate the temperature fluctuations. Error bars represent standard error of the means $(n=3)$. 


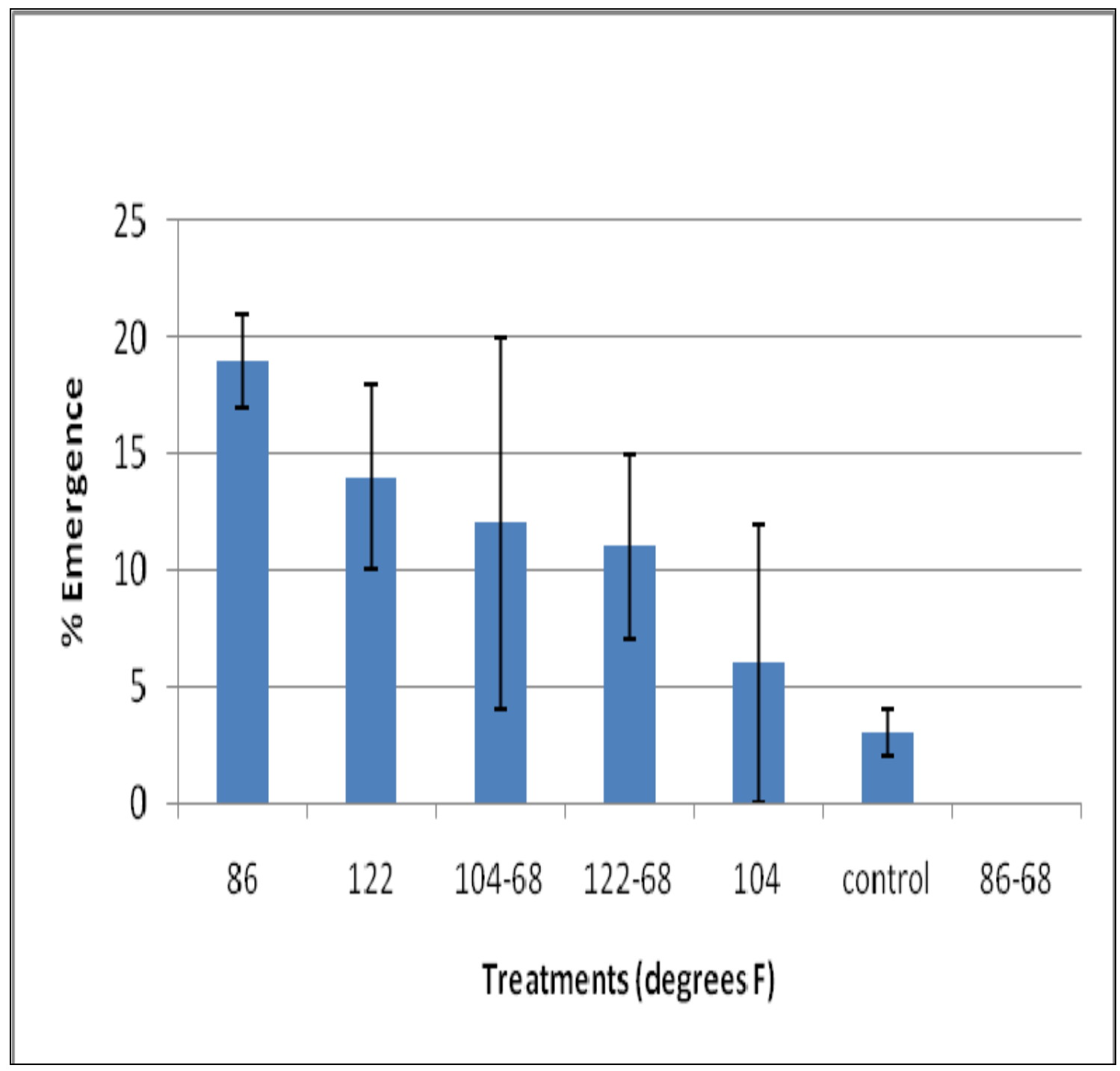

Figure 11. The effect of soil incubation at constant temperatures versus temperature fluctuations on spinach seedling emergence/survival in root rot infested soil. Treatment numbers are ${ }^{\circ} \mathrm{F}$ (all treatments lasted for eight weeks). Hyphenated numbers indicate the temperate fluctuations. Error bars represent standard error of the means $(n=3)$. 


\section{Cover crop/green manure experiment}

Control plots, or those left fallow (except for a small amount of weeds) supported the highest emergence rates for both pea and spinach (Fig.12). Pea and spinach emergence in the control ranged from 55\% to $17 \%$, respectively. Although a trend was found showing decreased seedling emergence with increased cover crop biomass (Fig.13 and Fig. 14), the analysis of co-

variance was inconclusive as to whether the decreased emergence of peas and spinach was related to the type of cover crop or the amount of biomass left as green manure. There was also no difference noted in pea and spinach crop emergence when green manures were cut two weeks, one week or the day of planting, except for the emergence in peas planted the day of green manure application. Peas planted immediately after the incorporation of field peas showed emergence rates lower than peas planted one and two weeks after the application of field pea as a green manure.

All results reported in imperial units can be converted to SI units referring to appendix F. 


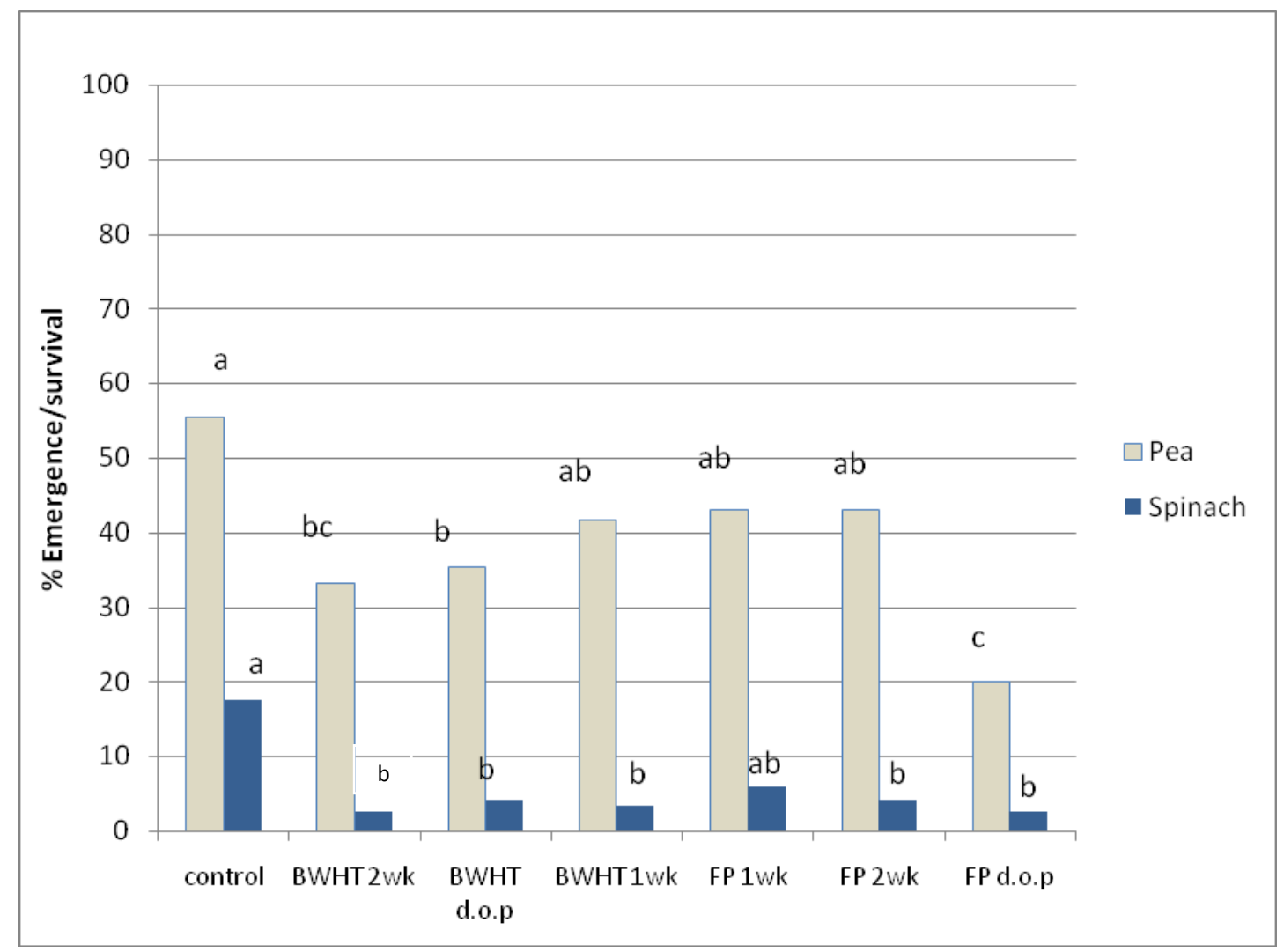

Figure 12. Emergence of pea and spinach (after 21 days) when planted into soil treated with cover crop/green manure, cut and tilled into the soil at different intervals prior to planting. BWHT= buckwheat cover crop; FP= field pea cover crop; $2 \mathrm{wk}=$ cover crop cut and tilled down two weeks prior to planting; 1 wk=cover crop cut and tilled down one week prior to planting; d.o.p= cover crop cut and tilled down on the day of planting. Means seperated by Tukeys-kramer HSD. 


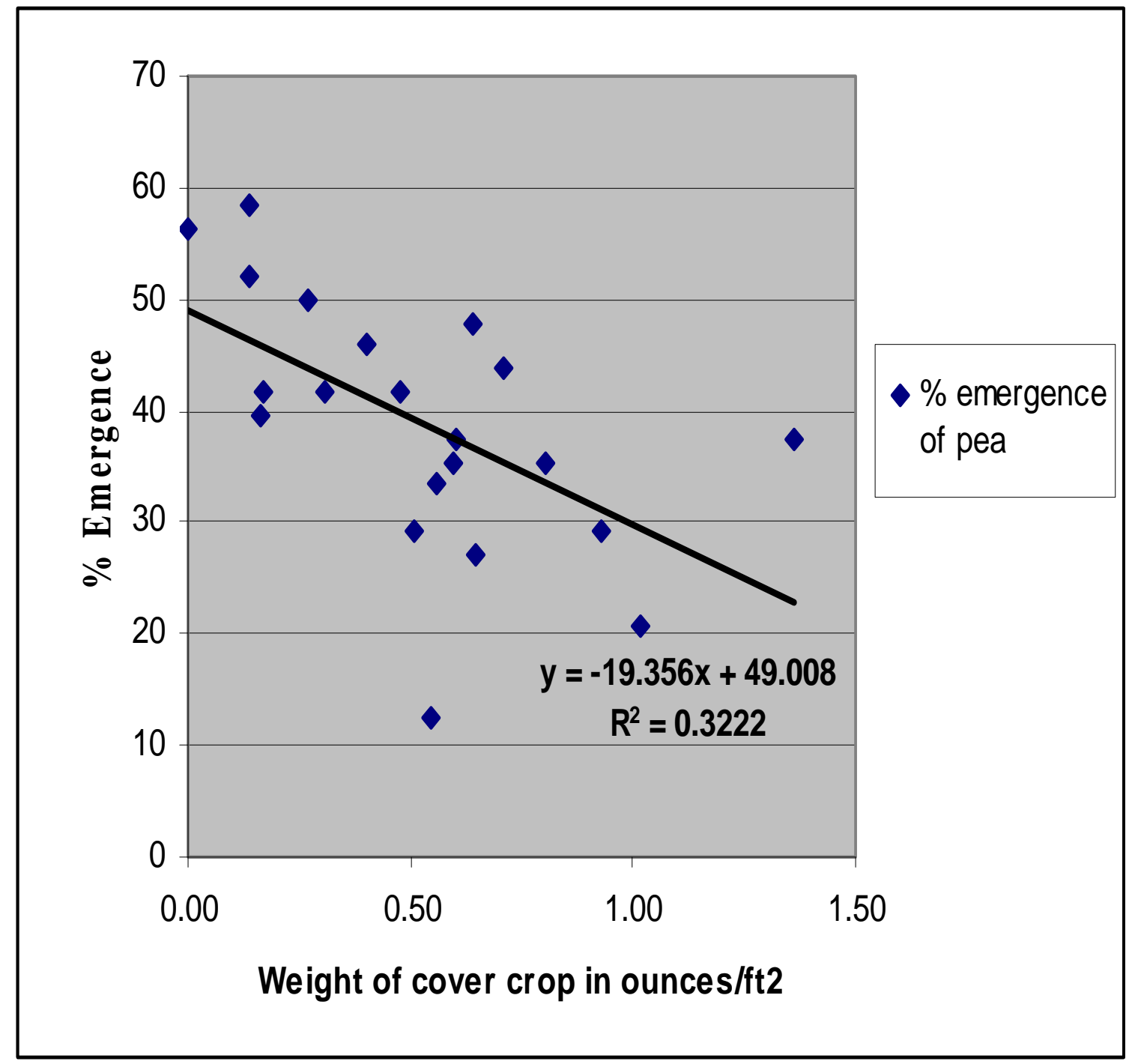

Figure 13. Regression analysis of pea emergence in relationship to the dry weight of the cover crop (oz/ft2). 


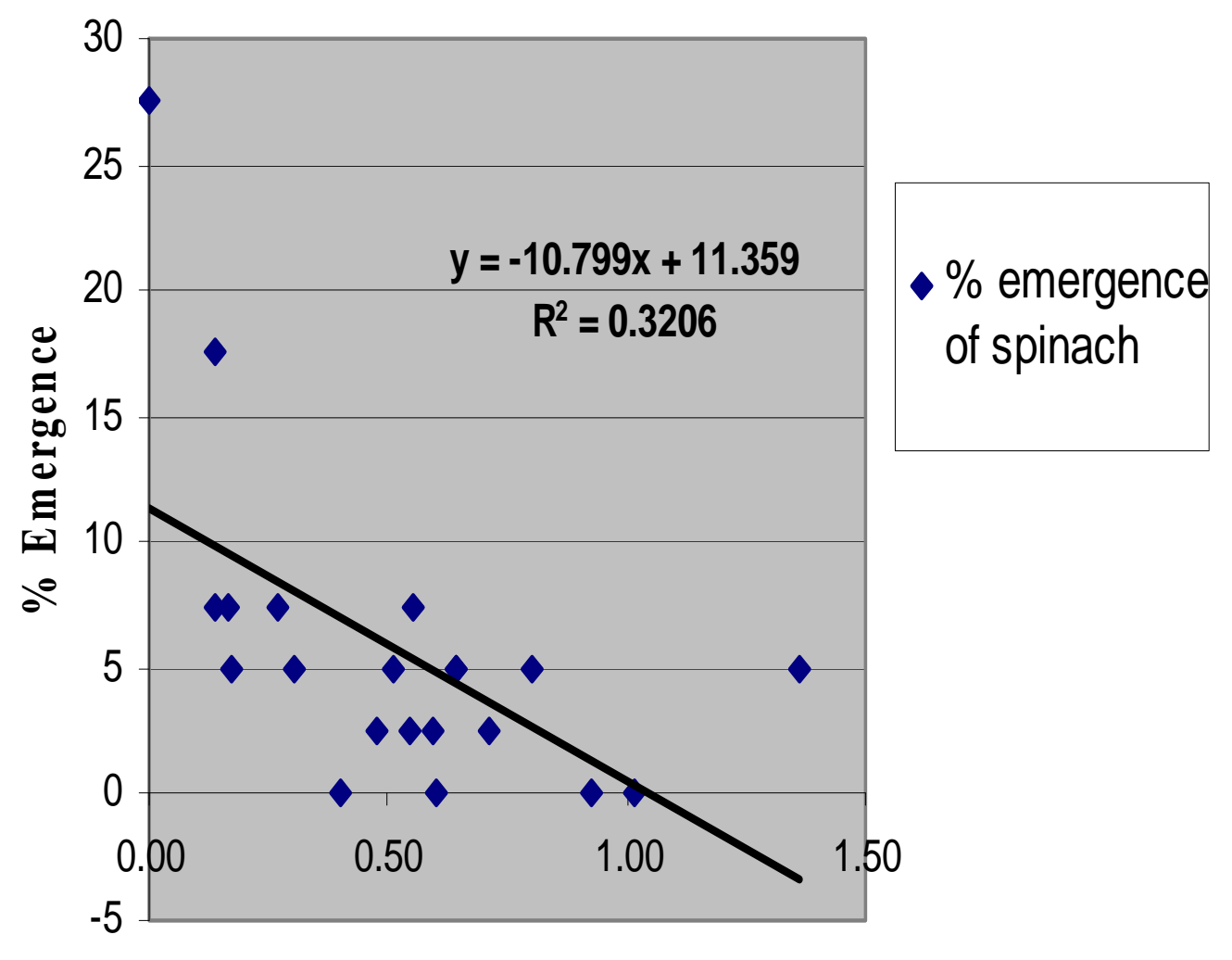

Weight of cover crop in ounces/ft2

Figure 14. Regression analysis of spinach emergence in relationship to the dry weight of the cover crop (oz/ft2). 


\section{Cultural manipulations and the Rhizosphere}

Emergence - cultural methods

Transplanting of both pea and spinach resulted in survival rates between 90 and $100 \%$ in the spring and fall seasons in both years of my study. Transplanting also provided higher crop stands than all other treatments $(\mathrm{P}=0.05)$ (Table 3$)$. Slightly higher survival rates for transplanting were observed in fall than spring seasons. In the fall, pea emergence was second highest, after the transplanting treatment, in the vermicompost troughs. No significant difference was observed between the high and low troughs. Vermicompost treatments showed emergence rates of $39 \%$ and $27 \%$, for the low and high treatment, respectively. Although these emergence percentages were higher than the control they were still significantly lower than the emergence (survival) observed in the transplanting treatment (99\%). No other treatment differed from the control. In the spring, pea emergence was second highest in dairy troughs (again no difference between the sizes of the troughs). All other treatments were statistically the same as the control. Similar to observations made on pea emergence, spinach emergence in the fall was (also) second highest in vermicompost troughs. Spinach emergence was $29 \%$ and $43 \%$ in low and high vermicompost troughs. Compared to the control no other treatments had statistically significant impacts on seed emergence in the fall. In the spring, only transplanting provided a spinach stand significantly above that of the control (90\% survival by transplant compared with $<10 \%$ emergence for all other treatments) (Table 3). 
Table. 3: Mean emergence (\%) of spinach and peas after 21 days in fall 2006 and spring 2007

\begin{tabular}{|l|c|c|c|c|}
\multicolumn{2}{|c|}{ Fall-Spinach } & Spring-Spinach & Fall-Peas & Spring-Peas \\
\cline { 1 - 4 } Transplant & $95 \mathrm{a}^{*}$ & $90 \mathrm{a}$ & $99.1 \mathrm{a}$ & $93 \mathrm{a}$ \\
\hline Control & $0 \mathrm{c}$ & $4.3 \mathrm{~b}$ & $11.4 \mathrm{~d}$ & $10.3 \mathrm{bc}$ \\
\hline $\begin{array}{l}\text { Vermicompost- } \\
\text { High }\end{array}$ & $43.3 \mathrm{~b}$ & $2.6 \mathrm{~b}$ & $27.7 \mathrm{bc}$ & $8.6 \mathrm{c}$ \\
\hline $\begin{array}{l}\text { Vermicompost- } \\
\text { Low }\end{array}$ & $29.1 \mathrm{~b}$ & $5.3 \mathrm{~b}$ & $39.2 \mathrm{~b}$ & $8 \mathrm{c}$ \\
\hline Ridge-6in. & $2.5 \mathrm{c}$ & $6 \mathrm{~b}$ & $15.9 \mathrm{~cd}$ & $16.6 \mathrm{bc}$ \\
\hline Ridge-3in & $1.6 \mathrm{c}$ & $7.6 \mathrm{~b}$ & $16.4 \mathrm{bcd}$ & $20.3 \mathrm{bc}$ \\
\hline Dairy-High & $3.3 \mathrm{c}$ & $1.6 \mathrm{~b}$ & $19.6 \mathrm{bcd}$ & $31.3 \mathrm{~b}$ \\
\hline Dairy-Low & $6.6 \mathrm{c}$ & $8.6 \mathrm{~b}$ & $15.9 \mathrm{bcd}$ & $21 \mathrm{bc}$ \\
\hline
\end{tabular}

* Means separated by Tukey-Kramers HSD. P $<0.05$ 
Rhizosphere data: Moisture content and temperature

Temperature and moisture sensors were placed in only one replicate of each treatment (Appendix D). In fall, temperatures ranged from $64.8^{\circ} \mathrm{F}$ in the transplant to $66.8^{\circ} \mathrm{F}$ in the dairy compost. In terms of treatments which produced significant results (reviewed above), the vermicompost high, low and control all had similar temperatures $\left(66.2^{\circ} \mathrm{F}, 66.3^{\circ} \mathrm{F}\right.$, and $66.2^{\circ} \mathrm{F}$, respectively). Neither ridge treatment $\left(65.0^{\circ} \mathrm{F}\right.$ and $65.5{ }^{\circ} \mathrm{F}$ for 6 in. ridge and 3 in. ridge, respectively) was warmer than the control $\left(66.2^{\circ} \mathrm{F}\right)$. In the spring, temperatures ranged from $68.5^{\circ} \mathrm{F}$ in the high vermicompost to $72.8^{\circ} \mathrm{F}$ in the 7 in. ridge. The transplant $\left(68.5^{\circ} \mathrm{F}\right)$ was one degree cooler than the control $\left(69.6^{\circ} \mathrm{F}\right)$. The high-dairy treatment which was the only treatment that significantly impacted pea emergence (since no other treatments impacted spinach emergence in the spring) was $68.6^{\circ} \mathrm{F}$. Moisture varied much more widely between treatments than the temperature did: from $0.2 \mathrm{kPa}$ in the low-dairy treatment to $47.1 \mathrm{kPa}$ in the transplant treatment in the fall and $11.6 \mathrm{kPa}$ (low dairy) to $52.3 \mathrm{kPa}$ (transplant) in the spring. Again, to highlight the treatments that had significant impact: the fall moisture data for the high and low vermicomposts was $17.3 \mathrm{kPa}$ and $19.9 \mathrm{kPa}$ compared to $23.0 \mathrm{kPa}$ for the control. In the spring, the high-dairy treatment averaged $19.3 \mathrm{kPa}$ differed vastly from the control which averaged 45.6 $\mathrm{kPa}$. There was no clear or consistent trend found between temperature/moisture and seedling emergence/survival of either peas or spinach.

\section{Emergence -Root Guardian}

In the trials of fall 2007 and spring 2008, following preliminary studies we compared a control treatment to transplanting and the biological control Root Guardian. No significant differences were observed between the Root Guardian treatment and the control in either pea or spinach emergence. In the fall, pea seedling emergence/survival was low, $12 \%$ and $18 \%$, for the 
control and root guardian treatment respectively, compared to a 96\% survival in the transplanting treatment. No spinach survived under any treatment in fall 2007 (Fig. 15). In spring 2008 the same experiments comparing Root Guardian, the transplanting treatment and control methods, transplanting again resulted in the highest pea and spinach survival (Fig.16). Similar to the fall results, pea emergence was low in the control and Root Guardian treatments, $15 \%$ and 3\% respectively. Transplanted peas showed 88\% emergence/ survival rates. Spinach emergence was $0 \%$ and $8 \%$ in the control and Root Guardian treatments, respectively, compared to the $83 \%$ emergence/survival in the transplant treatment.

All results reported in imperial units can be converted to SI units referring to appendix F. 


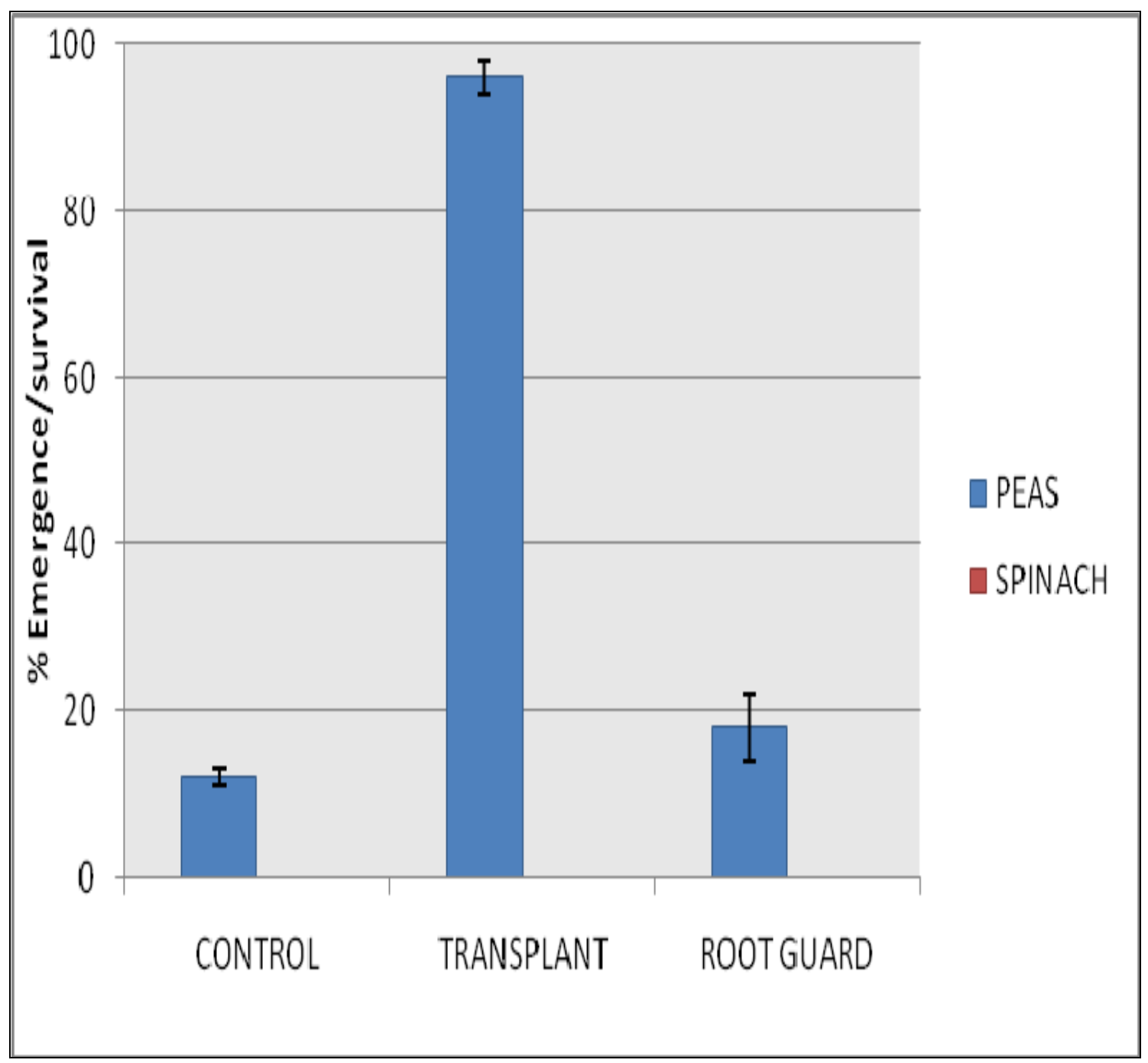

Figure 15. Mean\% emergence/survival of peas and spinach treated with root guardian, transplanted, and control in fall 2007. Error bars represent standard error of the means $(n=3)$. No spinach survived in any treatment. 


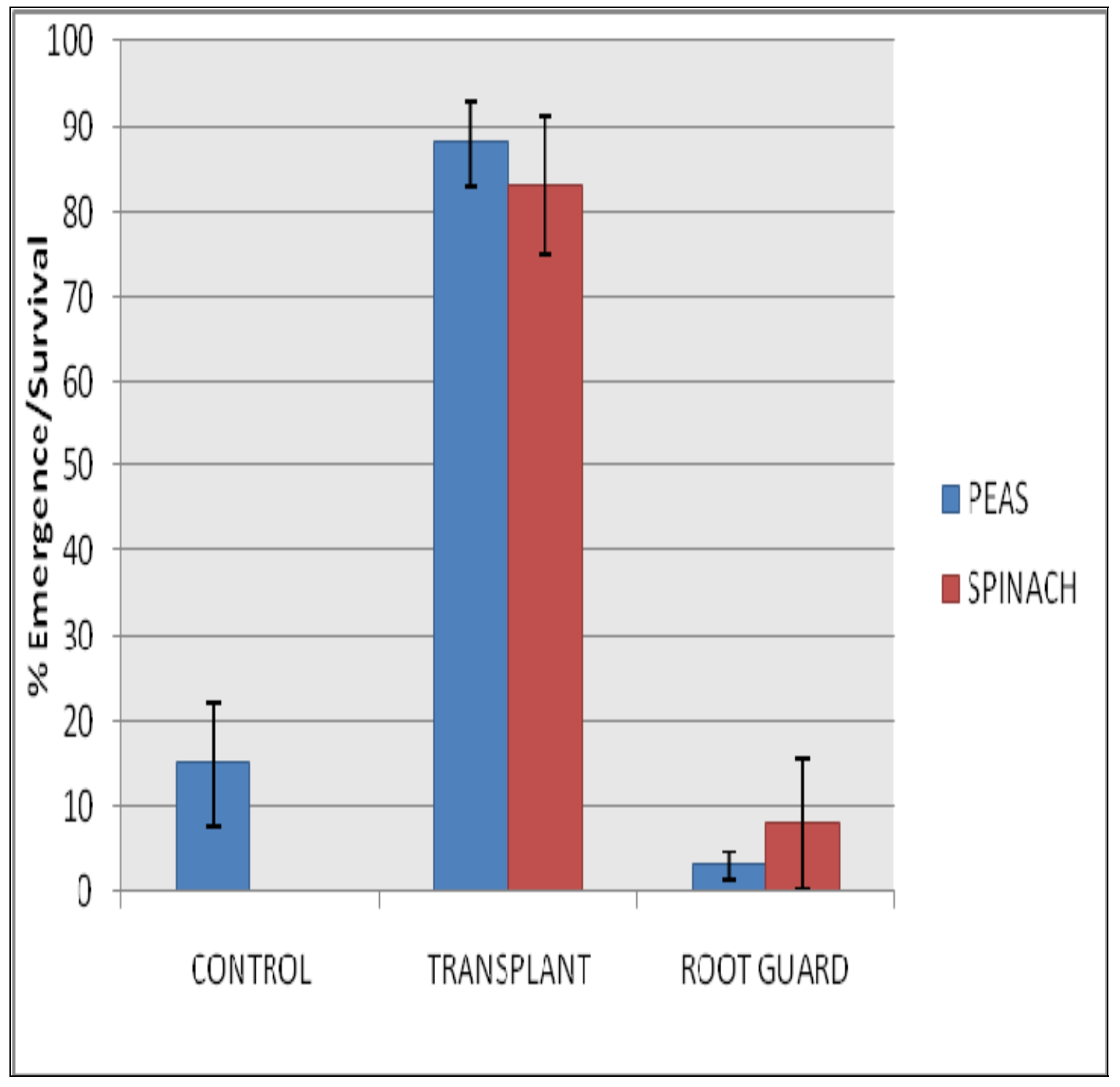

Figure 16. Mean \% emergence of peas and spinach treated with root guardian, transplanted, and control in spring 2008. Error bars represent standard error of the mean $(n=3)$. 


\section{Chapter 4- Discussion}

\section{Soil OM and Disease Incidence}

These results did not support the hypothesis we formulated that the percentage of seedling emergence (and survival) would show a positive correlation with soil organic matter (OM). In addition, we also did not see a positive effect of the additional fertility input in the high input plots on seedling emergence. Although the results did not support the contention that higher fertility and/or organic matter could improve seedling stands, it does illustrate the unpredictability of enhancing soil disease suppressive qualities via the addition of composts or increasing OM content (Manici, 2004). A study by Abassi et al (2002) in which tomatoes grown in compost amended soil were at once more susceptible to foliar diseases, but less susceptible to fruit rot further illustrates the vastly variable influences that compost may or may not have on disease control. The addition of mature composts to soil undoubtedly yields numerous benefits including improvements in tilth, drainage, plant available nutrients and biodiversity in the soil ecosystem (Manici, 2004; Abbasi et al., 2002; Sullivan, 2004). In addition, in cases where soils are conducive to disease and have received compost amendments, research has found that crop plants which were not lost to disease have a generally enhanced yield and increased vitality than plants grown in (conducive) soil without compost amendments (Childers, 2005; Abbasi et al, 2002; Baysal et al., 2008). Our experiments did not measure subsequent yield. Although it is reasonable to expect that the surviving plants would yield higher, the extremely low percent emergence observed in some of the plots would unlikely result in economically viable yields.

Finally, and inconsideration of the larger scheme in which the peas and spinach are planted in the Market Garden, the cultural methods used may have a larger role in the persistent problem with root rot than high versus low input or even the addition of compost. Because peas and spinach are planted early in the spring, after only a small window of time has expired 
between turning under the cover crop/green manure and planting, it is feasible that the resulting spike in pathogens (Baysal et al., 2008 and Manici, 2004) simply overwhelms any suppressive effect offered by the addition of dairy compost or higher OM in high input plots. It may be this particular circumstance that thus renders the high input plots no more suppressive to root rot disease than the low input plots. In support of this contention, the experiment using buckwheat and field peas (see below) clearly illustrate the detrimental effect of not allowing sufficient time between incorporating green manure and seeding a crop into soil already known to be plagued by root rot.

\section{Solarization}

\section{Field Experiments}

The data from the field experiments were similar to other research in which the survival (or emergence) of crops was (most) enhanced by long periods of soil solarization of disease conducive soils (Katan, 1981). At least for research purposes the field experiments showed that crops sown in solarized soils show increased seedling stands. However, even in the plots with the highest emergence, those treated with eight weeks of solarization, total emergence was not high according to grower's standards, especially in the case of spinach. Although solarization treatments continued to have some significance in the spring season, its effect was much less pronounced than in the previous fall. The slow, but evidently re-charging of the disease incidence in the following spring further reduces any practical appeal of this technique to growers. Despite the fact that other research has found the effects of solarization to offer multiple-season disease suppression (Pinkerton, 2002), these experiments likely failed to do so because temperatures were not high enough to kill a substantial number of the pathogens. Based on the temperature data collected, we further hypothesize that soil temperatures did not reach lethal levels deeper in the soil profile. (The fluctuations seen in the daily highs varied greatly due to day to day weather, 
especially cloudy/rainy conditions.) If this is true and pre-planting tillage reintroduced pathogens from deeper soil to the surface soil, then it would help explain why disease incidence was still prevalent in the spring. The single exception to this trend was displayed when spinach emergence in Field II was actually higher in the spring than in the fall immediately after solarization. This could be attributed to a cultural or climatic anomaly such as the unusual hot and dry fall of 2007 . Despite these observations, further research is warranted to fine tune techniques in order to lead to possible practical applications. Testing new plastic technology such as IR blocking plastics (which do not allow heat to escape) or biodegradable variations of polyethylene need to be investigated as do experiments which extend the solarization process for up to 10 or 12 weeks. In combination these could still provide viable results that are attainable to small growers in West Virginia.

\section{Greenhouse experiments}

The first greenhouse experiment further illustrated the important relationship between soil incubation temperature, duration, and the decline of the pathogens (measured by disease incidence). Interestingly, the temperatures at which we saw significant improvements in emergence (113 and $\left.122^{\circ} \mathrm{F}\right)$ in the greenhouse experiment were rarely if ever reached in the field experiment, despite the fact that improvements in emergence were observed in the field plots. The reduction in emergence in the greenhouse experiments compared to the field experiments is likely a factor of the incubation process, and suggests that there is more to solarization than merely duration of temperature (Katan, 1981; Pinkerton, 2000). This highlights the poorly understood mechanisms of how exactly solarization reduces pathogens although Katan (1981) suggests that solarization may work due to many interactions: physical, chemical, and biological. The odd circumstance of finding spinach emergence more enhanced than pea emergence in the greenhouse (directly opposite of field results) remains unexplained. The results of the second greenhouse experiment do not allow us to conclude if long periods of high heat alone or fluctuations of high 
and low temperatures are responsible for the effect of solarization on emergence we saw. Some research (Pinkerton, 2002; Tjamos, 1995) suggests the importance of both factors. But the greenhouse results combined with the field results are reflective of research that reported Pythium and Rhizoctonia to be reduced by solarization, but not Fusarium (Pinkerton et al, 2002).

Therefore, once again the synergistic effect of this particular complex may explain why root rot disease is still moderately to heavily persistent in my study even after solarization. At best trends seen in the greenhouse experiments corroborated with more significant results in the field experiments as well as other research (Katan, 1981; Pinkerton, 2000 and 2002; Hagan,2000), but in and of themselves the results from the greenhouse experiments provided little more insight into the means of how solarization effects pathogens.

\section{Cover crops}

In order to study the potential of green manures in suppressing root rot populations during short spring and fall growing seasons we tested the possibility of significantly shortening the recommended time interval (Anon.,1998) between incorporating a green manure and planting. However, the results of my experiment incorporating cover crops the day of planting, or 1 to 2 weeks before planting clearly highlight the importance of an even longer time interval needed between incorporating cover crops as green manures and planting the market garden crops. Previous research has suggested that the decaying biomass from incorporated green manures and the saprophytic nature of some of the pathogens results in a temporary but increased pathogenicity (Hodges, 2003 and Davis, 1999). Although our experiment did not illuminate which factor (type of cover crop or amount of biomass at planting) played a greater hindrance to pea and spinach emergence, it nevertheless demonstrated that the vegetable crops were better off planted in fallow or bare soil. The inconclusive nature of the analysis is most likely related to the wide variance in amount of biomass observed within each treatment. Clearly none of the time 
intervals in our experiment were long enough to avoid the negative effects associated with decaying biomass. Any suppressive or positive effects ascribed to cover crops in managing root rot population (Williams-Woodward, 1997 ; Anonymous, 1998; Baysal, 2008) were also clearly not enough to compensate for the peak in pathogen population we may have created with the incorporation of green manures (Manici, 2003). The long times recommended between turning under a green manure and planting results in too short of a growing season for the early season crops we would like to grow. Since our experiment was not designed to test long term effects, we chose to discontinue further experiments with cover crops and their potential to suppress root rots in cool season crops in market garden settings.

\section{Cultural Techniques}

Despite commonly prescribed advice suggesting that improving drainage of a seed bed by planting seeds on a ridge will help in controlling root rot, the results of my experiments did not support such assertions. In healthy soil, ridged seed beds may benefit seed germination and early growth with increased temperatures and drainage. However in our situation the treatments simply had little impact on suppressing the incidence of root rot disease. This may be the result of a pathogen complex in which one genus thrives in cultural conditions where others do not (Kumar et al. 1999). For example Rhizoctonia prefers a warmer/drier soil than Pythium which is most pathogenic in cool/moist conditions (Hodges, 2003). Interestingly, the only treatment that resulted in higher seedling stands was the vermicompost treatment. But in terms of consistency from season to season as well a across crops, we see that as a buffer zone, compost does not provide adequate or reliable protection from the pathogen-laden field soil because troughs of a dairy manure compost of the same size did not show improved seedling emergence. This may illustrate the tenacity of the pathogens and their ability to migrate considerable distances in the rhizosphere in order to reach sprouting seeds. This is supported by other research which reported 
that Rhizoctonia can spread distances of 6-9 in. over the course of 16 days (Kumar et al., 1999), a distance and time frame well within the scope of our experiments. Once the root rot causing organism reach the row with seedlings their movement is even easier. For example it has been shown that the motile spread of Pythium in moist soils is more evident along crop rows as the pathogens are attracted to each nearby crop plant (Hodges, 2003). Furthermore, in terms of the anticipated antagonistic effect the microflora of the composts might have had on the pathogens, my experiments further illustrated the extreme variability in disease suppression results achieved with compost. In short, the evidence hinted at the suppressive effects of compost on root rot causing organisms. However, the increase in seedling emergence found in the vermicompost (fall) and dairy (spring) troughs over the controls was decidedly not on an economical viable level. The pathogen population may just be too overwhelming for (economically) effective antagonistic suppression to take place. In any case, the inconsistent results between the two seasons demonstrated that these methods are unpredictable in resulting in an improved seed stand.

Finally, these trials indicated that a soil drench with the biological control Root Guardian was an ineffective treatment to control root rots, as seedling emergence observed in this treatment was not statistically different from the control. This was disappointing due to the relative ease of treatment and the positive acclaim with which many organic growers declare for biocontrol. However many researchers have come to similar conclusions (Lumsden and Locke, 1989; Naseby et al., 2001; and Kotcon, unpublished). This further demonstrates the difficulty of industrializing biological control in microbial communities, and there is much more research needed to understand and therefore predict the host-pathogen-antagonist behaviour. Again, the severe disease pressure may have played a role, as these treatments may be effective in low to medium disease pressure situations.

Transplanting was by far the most successful method we tested to control or circumvent the root rot disease complex encountered in my study. This appears to be a very tangible and 
flexible solution which has not been previously highlighted in any other research as far as we ascertain. In light of the high and consistent success of the transplanting method in our experiments, we realize the technique warrants the discussion of the increase in time and labor it may involve. Although the transplanting method increased the planting time/labor by 25\%, it may nevertheless be a viable solution to a grower whose other option is to have no saleable crop of peas or spinach due to root rot. (It is worth noting that transplanting may not prove economically efficient in scenarios where there is no risk of crop loss due to disease in the first place.) In addition, we project that this could be reduced by the efficiency of a larger scale farm operation. In all reality the economics of using this method are best determined case by case as each grower's cost/benefit analysis will be different. However, we do propose that the benefits of using this technique are not limited to the mere skirting of root rot disease. Transplanting not only insures the growth of a crop in the face of root rot, it also provides an avenue for season extension (transplants can be started indoors and set out at the earliest date possible), which in turn may provide higher price premiums for the grower. Additionally, since transplanting relies on the natural resistance the plant develops with maturity, there is little cause for concern over an 'arms race' with the evolving pathogens. One regional grower who tried transplanting peas and spinach (independently of this research project) reported that the success of the crops was worth the added effort and that she would continue using this method. ( Leslie Zuck, Spring Mills, PA, personal communication, 2008). 


\section{Chapter 5-Conclusions}

The outcomes of this research were productive in better understanding root rot from a technical standpoint of how to manage the disease. In congruence with the objectives stated in the beginning of this thesis, the conclusions can be summed up in four parts:

First, in light of examining the relationship between soil organic matter and disease incidence, we concluded that the amount of OM made little, if any, impact on the level of root rot disease incidence. Certainly there are numerous well documented advantages to adding compost to fields, however doing so for the explicit purpose of rendering the soil suppressive to what is a very durable and highly present pathogen complex will have little or no effect on enhancing crop stands.

Secondly, in regard to the efficacy of solarization techniques in controlling root rot pathogens, results indicated a clear increase in crop stands in soil that was solarized. This effect was enhanced by an eight week period of solarization over a 4 week period of solarization, and further, the effects were still noticeable in the following spring. However, we must differentiate between data that are significant in terms of statistics and results that are applicable to growers. With this in mind we would not recommend solarization to growers in West Virginia as a means of controlling root rot in peas and spinach. It is uneconomical for this purpose alone as it implies a field must be out of service (and thereby not producing a cash crop that would otherwise be there) for a significant period of the growing season , and the resulting yield in peas and/or spinach is unlikely to warrant the cost of time and material spent on solarization.

Third, the cover crop experiment clearly illustrated that common cover crops such as buckwheat or fieldpea serve no purpose in suppressing root rot pathogens, at least not in the short term. Additionally, this experiment highlighted the importance of planning adequate time 
(recommended $>3$ weeks) between turning under a green manure and planting crops which are susceptible to root rot, especially if root rot is already a suspected disease problem.

Finally, planting techniques that promote drainage, increase temperatures and/or an increase of antagonistic microbes were not effective in suppressing root rot disease. Oppositely, transplanting provided reliable, healthy crop stands. Due to the overwhelming success of the transplanting method, this technique is recommended to growers whose fields show poor stand of peas and spinach due to root rot. As in any integrated disease management program, we do not presume that transplanting is the end all answer to root rot. However since transplanting can offer the grower flexibility in planting scheduled, provides consistent results and is easily realized, it serves a tremendous potential in organically controlling root rot in peas and spinach. 


\begin{tabular}{|c|c|c|c|c|}
\hline \multicolumn{5}{|l|}{ Effect Test :Field I } \\
\hline Source & DF & $\begin{array}{l}\text { Sum of } \\
\text { Squares }\end{array}$ & F-ratio & Prob $>F$ \\
\hline Treatment & 2 & 8527.0000 & 50.2491 & $<0.0001$ \\
\hline Year Solarized & 1 & 150.2222 & 1.7705 & 0.1896 \\
\hline Season & 1 & 6384.5000 & 75.2470 & $<0.0001$ \\
\hline Treatment*Year Solarized & 2 & 105.4444 & 0.6214 & 0.5415 \\
\hline Treatment*Season & 2 & 1948.0000 & 11.4795 & $<0.0001$ \\
\hline Year Solarized *Season & 1 & 2592.0000 & 30.5490 & $<0.0001$ \\
\hline $\begin{array}{l}\text { Treatment*Year } \\
\text { Solarized*Season }\end{array}$ & 2 & 124.0000 & 0.7307 & 0.4868 \\
\hline Crop & 1 & 8800.2222 & 103.7184 & $<0.0001$ \\
\hline Crop*Treatment & 2 & 694.3889 & 4.0943 & 0.0228 \\
\hline Crop*Year Solarized & 1 & 249.3889 & 2.9393 & 0.0929 \\
\hline Crop*Season & 1 & 2.0000 & 0.0236 & 0.8786 \\
\hline Crop*Treatment*Year Solarized & 2 & 177.4444 & 1.0457 & 0.3593 \\
\hline Crop*Year Solarized*Season & 1 & 12.5000 & 0.1473 & 0.7028 \\
\hline $\begin{array}{l}\text { Crop*}^{*} \text { Treatment*Year } \\
\text { Solarized*Season }\end{array}$ & 2 & 343.0000 & 2.0213 & 0.1436 \\
\hline Crop*Treatment*Season & 2 & 2.3333 & 0.0138 & 0.9863 \\
\hline Whole-model Test & & & & \\
\hline Source & DF & $\begin{array}{l}\text { Sum of } \\
\text { Squares }\end{array}$ & $\begin{array}{l}\text { Mean } \\
\text { Square }\end{array}$ & Prob $>F$ \\
\hline Error & 48 & 4072.6670 & 84.8500 & $<0.0001$ \\
\hline
\end{tabular}


Appendix B- Summary of Field II solarization experiment

\begin{tabular}{|c|c|c|c|c|}
\hline \multicolumn{5}{|l|}{ Effect Test: Field II } \\
\hline Source & DF & $\begin{array}{l}\text { Sum of } \\
\text { Squares }\end{array}$ & F-ratio & Prob>F \\
\hline Treatment & 2 & 2847.7220 & 46.3463 & $<0.0001$ \\
\hline Crop & 1 & 10540.4440 & 343.0886 & $<0.0001$ \\
\hline Season & 1 & 920.1110 & 29.9494 & $<0.0001$ \\
\hline Crop*Treatment & 2 & 1239.389 & 20.1709 & $<0.0001$ \\
\hline Treatment*Season & 2 & 139.3890 & 2.2685 & 0.1252 \\
\hline Crop*Season & 1 & 2466.778 & 80.2929 & $<0.0001$ \\
\hline Crop*Treatment*Season & 2 & 498.389 & 8.1112 & 0.0020 \\
\hline Whole-model Test & DF & $\begin{array}{l}\text { Sum of } \\
\text { Squares }\end{array}$ & $\begin{array}{l}\text { Mean } \\
\text { Square }\end{array}$ & Prob $>F$ \\
\hline Error & 24 & 737.333 & 30.7200 & $<0.0001$ \\
\hline
\end{tabular}




\section{Appendix C-Summary of soil incubation in first lab experiment}

Effect test: temperature and duration of soil incubation on emergence of peas and spinach

\begin{tabular}{|l|c|c|c|c|}
\hline source & DF & Sum of squares & F-ratio & Prob>F \\
\hline Temperature ( $\left.{ }^{\circ} \mathrm{F}\right)$ & 4 & 19.9 & 5.7404 & 0.001 \\
\hline \# of weeks (4 or 8) & 1 & 20.41667 & 23.5577 & $<0.001$ \\
\hline \# of weeks*Temperature & 4 & 17.1667 & 4.9519 & 0.0024 \\
\hline $\begin{array}{l}\text { Crop* \# of } \\
\text { weeks*Temperature }\end{array}$ & 4 & 5.1 & 1.4712 & 0.229 \\
\hline \# of weeks* Crop & 1 & 2.81667 & 3.25 & 0.079 \\
\hline Temperature ( $\left.{ }^{\circ} \mathrm{F}\right) *$ Crop & 4 & 8.7667 & 2.5288 & 0.0555 \\
\hline & & & & \\
\hline Whole model Test & & Sum of squares & F-ratio & Prob>F \\
\hline source & 40 & 34.667 & 0.8667 & $<0.001$ \\
\hline error & DF & & & \\
\hline
\end{tabular}




\section{Appendix D-Temperature and moisture in averages under different cultural treatments.}

Mean temperatures $\left({ }^{\circ} \mathrm{F}\right)$ under different cultural treatments. Means accrued over 21 days. VC = vermicompost, $\mathrm{DC}=$ dairy compost

\begin{tabular}{|c|c|c|c|c|c|c|c|c|}
\hline & Control & Transplant & VC-High & VC-Low & $\begin{array}{l}\text { Ridge- } \\
6 \text { in. }\end{array}$ & $\begin{array}{c}\text { Ridge } \\
\text { 3-in. }\end{array}$ & $\begin{array}{l}\text { DC- } \\
\text { High }\end{array}$ & $\begin{array}{l}\text { DC- } \\
\text { Low }\end{array}$ \\
\hline Fall 2006 & 66.2 & 64.8 & 66.2 & 66.3 & 65.0 & 65.5 & 66.8 & 66.5 \\
\hline Spring 2007 & 69.6 & 68.5 & 68.5 & 69.6 & 72.8 & 70.1 & 68.6 & 69.7 \\
\hline
\end{tabular}

Moisture means $(\mathrm{kPa})$ of seed beds recorded under different cultural techniques. Means accrued over 21 days. $\mathrm{VC}=$ vermicompost, $\mathrm{DC}=$ dairy compost

\begin{tabular}{lcccccccc}
\hline $\begin{array}{l}\text { Moisture, } \\
\mathbf{k P a}\end{array}$ & \multicolumn{1}{c}{} & & & & & & \\
\hline & Control & Transplant & VC-High & VC-Low & $\begin{array}{c}\text { Ridge- } \\
\text { 6 in. }\end{array}$ & $\begin{array}{c}\text { Ridge } \\
\text { 3-in. }\end{array}$ & $\begin{array}{c}\text { DC- } \\
\text { High }\end{array}$ & $\begin{array}{c}\text { DC- } \\
\text { Low }\end{array}$ \\
\hline Fall 2006 & -23.0 & -47.1 & -17.3 & -19.9 & -29.9 & -34.3 & -0.8 & -0.2 \\
$\begin{array}{l}\text { Spring } \\
2007\end{array}$ & -45.6 & -52.3 & -52.3 & -45.6 & -46.5 & -51.3 & -19.3 & -11.6 \\
\hline
\end{tabular}




\section{Appendix E- Compost nutrient analysis}

\begin{tabular}{|c|c|c|c|c|c|c|c|c|}
\hline Compost & $\begin{array}{l}C: N \\
\text { Ratio }\end{array}$ & $N$ & $\boldsymbol{P}$ & $K$ & $\mathrm{NH}_{3}$ & $\mathrm{Cu}$ & $C a$ & $M g$ \\
\hline Dairy & 18.66 & 0.48 & 0.56 & 0.32 & 0.04 & 0.0002 & 1.02 & 0.10 \\
\hline Vermiculture & 28.95 & 0.70 & 0.77 & 1.37 & 0.06 & 0.0025 & 0.90 & 0.29 \\
\hline
\end{tabular}

Nutrient analysis of macronutrient, micronutrients, and carbon: nitrogen ratio of composts was done by the WVDA Nutrient Management Lab in Moorefield, WV. All nutrient values are reported as percentages. 


\section{Appendix F- Unit Conversion}

\begin{tabular}{cccc}
\hline $\begin{array}{c}\text { To covert U.S to SI multiply } \\
\text { by }\end{array}$ & U.S. Unit & SI Unit & $\begin{array}{c}\text { To convert SI to U.S. } \\
\text { multiply by }\end{array}$ \\
\hline $\mathbf{0 . 3 0 4 8}$ & $\mathrm{ft}$ & $\mathrm{m}$ & 3.2808 \\
$\mathbf{3 . 7 8 5 4}$ & gal & $\mathrm{L}$ & 0.2642 \\
$\mathbf{2 . 5 4}$ & inch & $\mathrm{cm}$ & 0.3937 \\
$\mathbf{0 . 0 2 5 4}$ & mil & $\mathrm{mm}$ & 39.3701 \\
$\mathbf{2 . 2 4 1 7}$ & ton/acre & $\mathrm{Mg}^{*} \mathrm{ha}^{-1}$ & 0.4461 \\
$\left({ }^{\circ} \mathbf{F}-32\right) / 1.8$ & ${ }^{\circ} \mathrm{F}$ & $\circ \mathrm{O}$ & $(1.8 \times 0 \mathrm{C})+32$ \\
\hline
\end{tabular}




\section{References}

Abbasi, P.A., J. Al-Dahmani, F. Shain, H.Hoitnik, S. Miller. (2002). Effect of compost amendments on Disease severity and yield of tomato in conventional and organic production systems. Plant Disease 86: 156-162.

Altieri, M.A. (1999) The ecological role of biodiversity in agroecosystems. Agriculture, ecosystems and environment 74: 9-31.

Anastasi, A., G. Varese, \& V. Marchisio. (2005) Isolation and identification of fungal communities in compost and vermicompost. Mycologia 97(1): 33-44.

Anonymous. Sustainable Agriculture Network. (1998). Managing Cover Crops Profitably.

Bardin, S.D., H.C Huang, J.R. Moyer. ( 2004). Control of Pythium damping-off of sugar beet by seedtreatment with crop straw powers and a biocontrol agent. Biological control: theory and application in pest management 29 (3): 453-460

Baysal, F., M.S. Benitez, M.d, Kleinhenz, S.A. Miller, B. B. Mcspadden Gardener. (2008) Field management effects on damping-off and early season vigor of crops in a transitional organic cropping system. Phytopathology 98 (5): 562-570.

Ben-Dor, E., and A. Banin. (1989). Determination of organic matter content in arid-zone soils using a simple "loss-on-ignition" method. Commun. Soil Sci. Plant Anal. 20:1675-1695.

Bjorkman, T. (1999) Proceedings. New England Vegetable and Berry Growers Conference and Trade Show, Sturbridge, MA. p.310-312.

Boehm, M.J., L.V. Madden, \& H. Hoitink. (1993). Effect of organic matter decomposition level on bacterial species diversity and composition in relationship to pythium damping-off severity. Applied and Environmental Microbiology 59(12): 4171-4179.

Childers, Todd Bradley. (2005). The Effect of Low and High Fertility Treatments on Soil Quality, Yields, Pest Incidence and Labor Requirements of a Post-transitional Organic Market Garden System, Master's Thesis, West Virginia University, [On-line Abstract].

Davis, R.M. \& J. Nunez. (1999). Influence of crop rotation on the incidence of Pythium and Rhizoctonia induced carrot root dieback. Plant Dis. 83:146-148.

Duniway, J.M. (2002). Status of Chemical Alternative to Methyl Bromide for Pre-Plant Fumigation of Soil. Phytopathology Vol. 92: 1337-1343.

Dyer, A.T, C.E. Windels, R.D.Cook, K..J. Leonard. (2007) Survival dynamics of Aphanomycees cochlioides oopspores exposed to heat stress. Phytopathology 97 (4): 484-491.

Edwards, C. A. (1998). The use of earthworms in processing organic wastes into plant growth media and animal feed protein. In: Earthworm Ecology, 327-354.

Hagan, A. (2000). Soil solarization for the control of nematodes and soilborne diseases. Alabama Cooperative Extension Service publication ANR 713.

Handelsman, J. and E.V. Stabb. (1996). Biocontrol of Soilborne Plant Pathogens. The Plant Cell vol 8: 1855-1869. 
Hodges, L. (2003). Damping off of seedling and transplants. University of Nebraska-Lincoln Extension publication G1522.

Katan, J. (1981). Solar heating (solarization) of soil for control of soilborne pests. Ann. Rev. Phytopathol. Vol.19: 211-36.

Kraft, J.M. and F.L. Pfleger. (2001) Compendium of Peas Diseases and Pests. Second edition. The American Phytopathological Society. St. Paul, Minnesota

Kumar, S., K. Sivasithamparam, J.S. Gill, \& M.W. Sweetingham. (1999). Temperature and water potential effects on growth and pathogenicity of Rhizoctonia solani AG-11 to lupin. Canadian Journal of Microbiology 45: 389-395.

Lockwood, J.L. (1964). Soil fungistasis. Annual Review of Phytopathology. Vol 2: 341-362.

Lumsden, R.D and J.C. Locke. (1989). Biological control of damping-off caused by Pythium ultimum and Rhizoctonia solani with Gliocladium virens in soilless mix. Phytopathology 79: 361-366.

Mandelbaum, R. and Y. Hadar. (1990). Effects of available carbon source on microbial activity and suppression of Pythium aphanidermatum in compost and peat container media.

Phytopathology 80(9): 800-804.

Manici, L.M, F. Caputo, \& V. Babini. (2004). Effect of green manure on Pythium spp. Population and microbial communities in intensive cropping systems. Plant and Soil 263: 133-142.

Miller, S.A., R.M Riedel, R.C Rowe. (1995) Damping Off and Root Rot of Beans. Ohio State University Extension Factsheet: HYG-3110-95.

Naseby, D.C, J.A Way, N.J Bainton, J.M. Lynch (2001) Biocontrol of pythium in the pea rhizosphere by antifungal metabolite producing and non-producind Pseudomonas strains. Journal of applied microbiology. 90 (3) 421-429.

Patterson, D.J. (1989) Stramenopila: chromophytes from a protistan perspective. The Cromophyte Algae: Problems and Perspectives pp.357-379. Clarendon Press, Oxford.

Pieczarka, D.J. and G.S. Abawi. (1978). Effect of interaction between Fusiarium, Pythium and Rhizoctonia on severity of bean root rot. Phytopathology 68: 403-408.

Pinkerton, J.N., Ivors, M. Miller, L. Moore. (2000). Effect of soil solarization and cover crops on populations of selected soilborne plant pathogens in western Oregon. Plant Dis.84: 952-960.

Pinkerton, J.N., K.L. Ivors, P.W. Reeser, P.R.Bristow, G.E. Windom. (2002). The use of soil solarization for management of soilborne plant pathogens in strawberry and red raspberry production. Plant Disease 86: 645-651.

Rivera, M.C., E.R.Wright, M.V Lopez, M.C. Fabrizio. (2004) Temperature and dosage dependant suppression of damping off caused by Rhizoctonia solani in vermicompost amended nurseries of white pumpkin. Phtyon. vol 53: 131-136.

Schroth, M.N., J.G. Hancock. (1982) Disease-suppressive soil and root colonizing bacteria. Science 216 (4553) 1376-1381. 
Szcech, M., W., Rondomanski, M.W. Brzeski, U. Smolinska, and J.F. Kotowski. (1993). Suppressive Effect of a Commercial Earthworm Compost on some Root Infecting Pathogens of Cabbage and Tomato. Biological Agriculture and Horticulture Vol. 10: 47-52

Sullivan, P. (2004) Sustainable management of soil borne diseases. ATTRA bulletin.

Sustainable Agriculture Network.. (1998). Managing Cover Crops Profitably.

Tjamos,E and D. Favel. (1995). Detrimental effects of sublethal heating and Talaromyces flavus on microsclerotioa of Verticilium dahliae. Phytopathology 85: 388-392.

Williams-Woodward, J.L., F.L. Pfleger, V.A. Fritz,\& R.R. Allmaras. (1997). Green manures of oat, rape and sweet corn for reducing common root rot in pea caused by Aphanomyces eutreiches. Plant and Soil 188: 43-48.

Yulianti, T., K.Sivasithamparam, \& D.Turner. (2006). Response of different forms of propagules of Rhizoctonia solani AG2-1(ZG5) exposed to the volatiles produced in soil amended with green manures. Annals of Applied Biology 148: 105-111. 